\title{
Desmosomal connectomics of all somatic muscles in an annelid larva
}

\author{
Sanja Jasek ${ }^{1}$, Csaba Verasztó ${ }^{1, \$}$, Emelie Brodrick ${ }^{1}$, Réza Shahidi ${ }^{1}$, Tom Kazimiers ${ }^{2}$, Gáspár \\ Jékely,* \\ ${ }^{1}$ Living Systems Institute, University of Exeter, Stocker Road, Exeter, UK \\ 2Janelia Research Campus, Ashburn, USA and kazmos GmbH, Dresden, Germany \\ ${ }^{\$}$ Present address: EPFL Campus Biotech, Geneva, Switzerland \\ "Correspondence: g.jekely@exeter.ac.uk
}

\begin{abstract}
Cells form networks in animal tissues through synaptic, chemical and adhesive links. In muscle tissue, cells often connect through desmosomes, adhesive structures anchored by intermediate filaments. To study desmosomal networks, we reconstructed 852 muscle cells and their desmosomal partners by serial electron microscopy in an entire larva of the annelid Platynereis. Muscle cells adhere to each other, to epithelial, glial, ciliated, and bristleproducing cells and to the basal lamina, forming a desmosomal connectome of over 2,000 cells. The aciculae - chitin rods that form an endoskeleton in the segmental parapodia - are highly connected hubs in this network. This agrees with the many degrees of freedom of their movement, as revealed by video microscopy. Mapping motoneuron synapses to the desmosomal connectome highlighted the extent of tissue influenced by individual motoneuron classes. Our work shows how cellular-level maps of synaptic and adherent force networks can elucidate body mechanics.
\end{abstract}

\section{Introduction}

Animals use somatic muscles to rapidly change body shape. Whole-body shape changes can drive swimming, crawling or other forms of movement. Moving appendages with exo- or endoskeletons and joints can have many degrees of freedom to support walking, flying and several other functions. This requires a large diversity of muscles with differential nervous control (Brierley et al., 2012; Charles et al., 2016; Cruce, 1974; Landmesser, 1978; McKellar et al., 2020).

To exert force and induce movements, contracting muscles must attach to other body parts. In many animals, muscle-force coupling is provided by desmosomes, stable adhesive junctions anchored by intermediate filaments. Desmosomes occur in cardiac and somatic muscles of both vertebrates and invertebrates. In the zebrafish heart for example, desmosomes connect cardiac myocytes to each other (Lafontant et al., 2013). In the lamprey, desmosomes frequently unite adjacent muscle fibres for lateral force transmission (Nakao, 1975). In the nematode Caenorhabditis elegans, hemidesmosomes link the pharyngeal muscles to the basement membrane (Albertson and Thomson, 1976) and the body-wall muscles to hypodermal cells that lie underneath the cuticle (Francis and Waterston, 1991). In leech, muscle cells have a high density of hemidesmosomes anchoring the cells to the basal lamina (Pumplin and Muller, 1983). 
These desmosomal connections form a body-wide network through which tensile forces propagate. This network comprises all muscles and all their cellular and non-cellular (e.g., cuticle, basal lamina) partners. We refer to this network as the desmosomal connectome, with muscles and other cells as nodes and desmosomes as links. How such networks are organised on the scale of the whole body in animals with complex muscles and appendages is not well understood.

To study the organisation of a body-wide tensile network and its motor control, here we reconstruct the desmosomal connectome of larval Platynereis dumerilii from serial electron microscopy images of an entire larva (Randel et al., 2015). $P$. dumerilii or 'the nereid' is a marine annelid worm that has been used as a laboratory animal (Fischer and Dorresteijn, 2004; Kuehn et al., 2019) to study developmental patterning (Gazave et al., 2017; Handberg-Thorsager et al., 2018; Özpolat et al., 2017; Schneider and Bowerman, 2007; Vopalensky et al., 2019; Žídek et al., 2018), the lunar control of reproduction (Poehn et al., n.d.; Zantke et al., 2014; Zurl et al., 2021), hormonal signalling (Schenk et al., 2016), photobiology (Ayers et al., 2018; Gühmann et al., 2015), neuromodulation (Williams et al., 2017), neuronal cell types (Vergara et al., 2017) and neuronal circuits (Bezares-Calderón et al., 2018; Randel et al., 2014).

In Platynereis, muscle development starts in the early non-feeding larval stages (Fischer et al., 2010). 3-day-old larvae have three main trunk segments, each with a pair of appendages called parapodia, composed of a ventral lobe (neuropodium) and a dorsal lobe (notopodium). Trunk muscles support turning during visual phototaxis (Randel et al., 2014), crawling on substrates (Conzelmann et al., 2013; Lauri et al., 2014) and a startle behaviour characterised by whole-body contraction and the elevation of the parapodia (BezaresCalderón et al., 2018). The parapodia are supported by internal chitinous rods called the aciculae (Hausen, 2005) and are also endowed with several chitinous bristles or chaetae. 6day-old larvae have a muscular, eversible proboscis (Fischer et al., 2010), a moving gut with visceral muscles (Brunet et al., 2016; Williams et al., 2015), and several sensory appendages (palps, antennae, cirri).

Platynereis larvae (1-6 day old stage) are 150-300 $\mu \mathrm{m}$ long and thus amenable to wholebody serial electron microscopy (EM) analysis. Here we use an available serial EM dataset of a 3-day-old larva (Randel et al., 2015) to reconstruct the desmosomal connectome and analyse how motoneurons innervate muscles.

\section{Results}

\section{Serial EM reconstruction of all muscle cells in the Platynereis larva}

To analyse the organisation of the somatic musculature, we first reconstructed all differentiated muscle cells by tracing along their longitudinal axis (skeletonisation) and marking the position of their soma (Figure 1, Figure 2). We analysed a previously reported whole-body serial TEM dataset of a 3-day-old Platynereis dumerilii larva (Randel et al., 2015) and used the collaborative annotation toolkit CATMAID, which allows skeletonisation, 3D visualisation and several types of quantitative analyses (Schneider-Mizell et al., 2016). In the skeletons, we annotated desmosomes and also skeletonised and annotated all desmosomal partners of muscle cells. We used these data to derive a desmosomal connectome for the larva (Figure 1 and see below). 


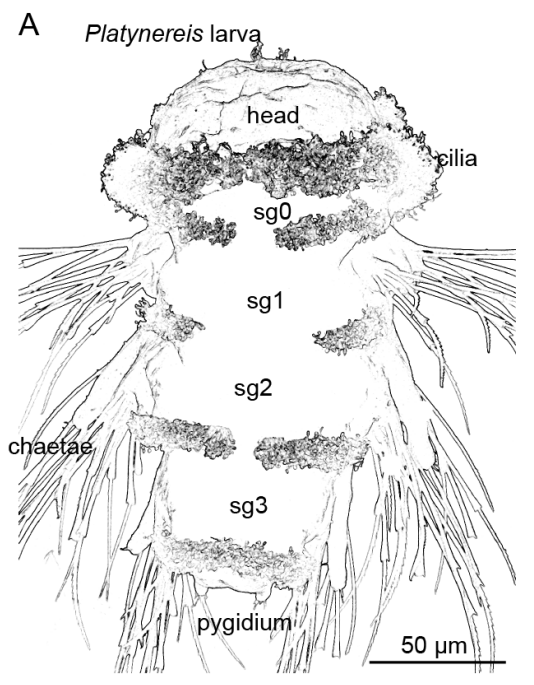

D

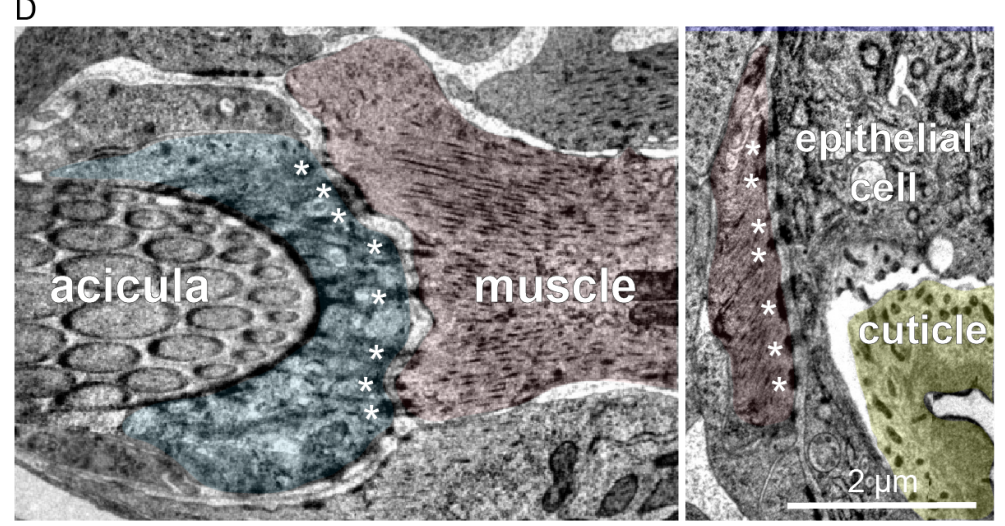

B

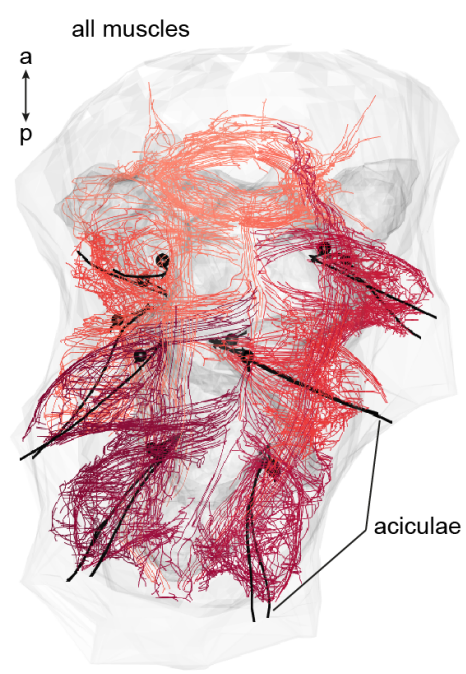

$\mathrm{E}$
C desmosomal partners

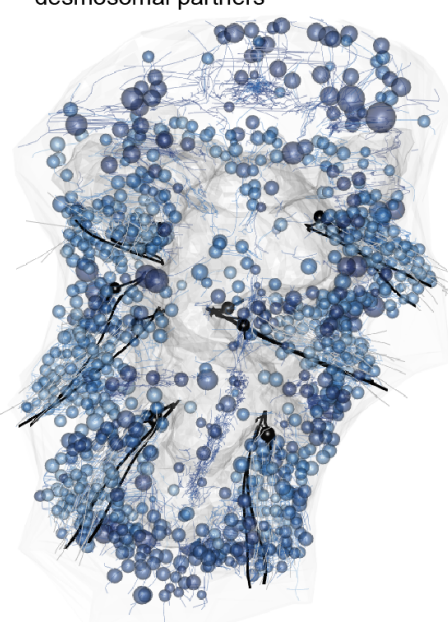

desmosomal connectome

Figure 1. Whole-body desmosomal connectomics in the Platynereis larva.

(A) Stylised scanning electron micrograph of a 3-day-old Platynereis larva. (B) Skeleton representation of the aciculae and all muscle cells in the larva. (C) Position of cell somas of all the cells that connect to muscle cells through desmosomes. (D) Transmission electron micrographs showing examples of desmosomal muscle-attachment sites. (E) Overview of the desmosomal connectome, comprising all muscle cells and their desmosomal partners. Nodes represent single cells (red, muscles; blue, other cells or basal lamina fragments), connections represent desmosomes. The graph is undirected. Abbreviations: sg0-3, segments 0-3.

All reconstructions, annotations and EM images can be queried in a CATMAID project at https://catmaid.jekelylab.ex.ac.uk, together with the synaptic connectome (Verasztó et al., 2020). The data can also be queried by the R package Natverse (Bates et al., 2020). All scripts used to generate the figures are available at https://github.com/JekelyLab/Jasek_et_al.

We identified 852 mononucleated muscle cells, most of them with a striated ultrastructure. Most muscle cells in the 3-day-old larva are somatic muscles (Table 1), visceral muscles develop at a later stage (Brunet et al., 2016). Based on their position and shape, we classified all muscle cells into eight main groups (Figure 2, Table 1): the longitudinal, anterior and posterior oblique, chaetal, acicular, transverse, digestive system (developing), and head muscles. 


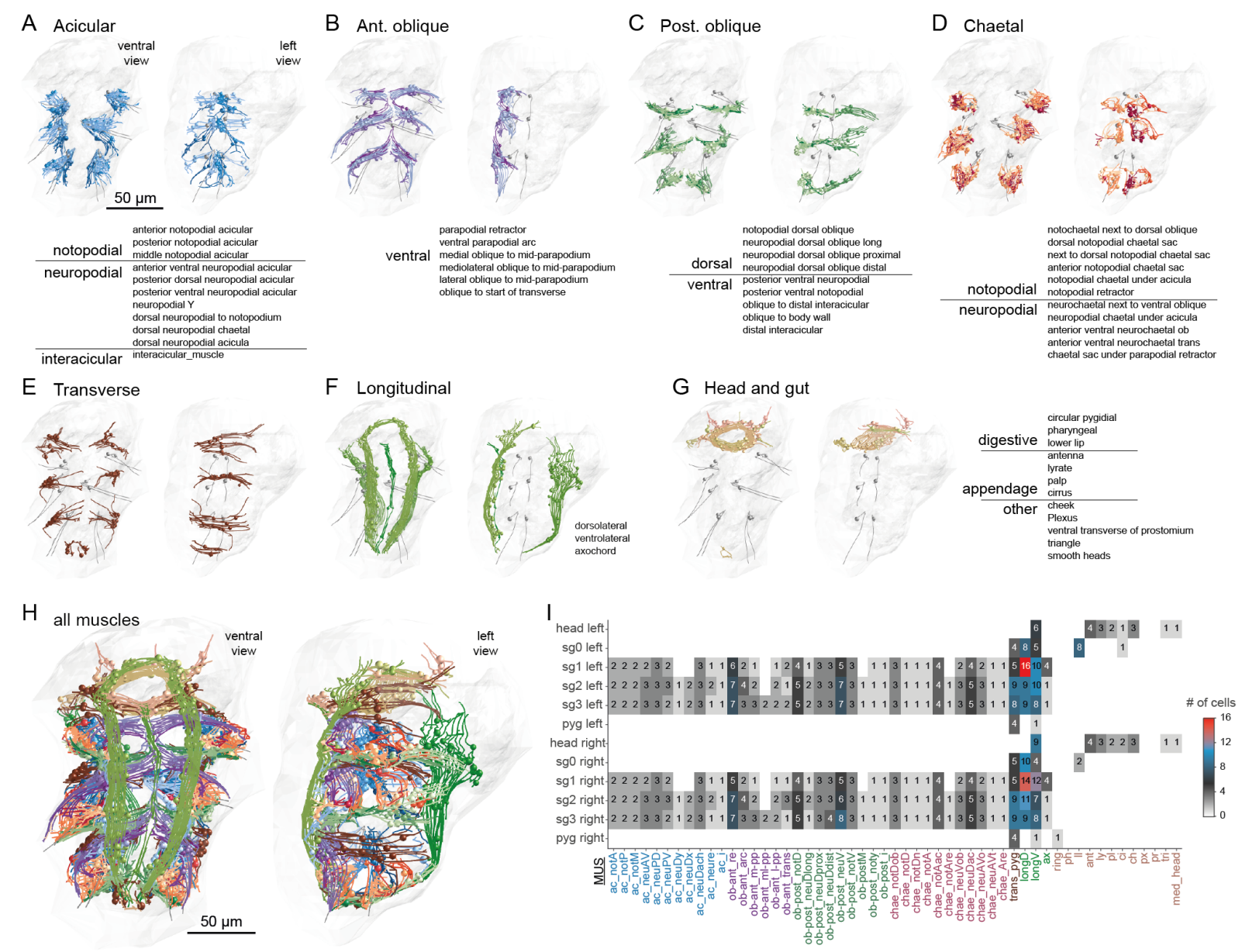

Figure 2. Classification and distribution of muscle cell-types in the 3-day-old Platynereis larva.

(A) All acicular muscles and their classification. (B) All anterior oblique muscles and their classification. (C) All posterior oblique muscles and their classification. (D) All chaetal muscles and their classification. (E) All transverse muscles (one type only). (F) All longitudinal muscles and their classification. (G) All muscles of the developing digestive system and the head and their classification. (H) All muscles, coloured by category. (I) Segmental and left-right distribution of all muscle cell-types. Numbers indicate the number of cells per type and body region. In $\mathrm{A}-\mathrm{H}$, the left panels are ventral, the right panels lateral-left views. The body outline is shown in grey.

\section{Classification, left-right stereotypy and segmental distribution of muscle cell types} The eight main muscle groups could be further subdivided into 53 distinct types (Figure 2, Table 1, Video 1). These 53 types represent anatomically distinct groups of cells that we classified based on their position, shape, motoneuron inputs and desmosomal partners. All types are composed of segmentally repeated sets with the same number of cells on the left and right body sides, with few exceptions (Table 1). The precise and repeated features of the anatomy and the type-specific patterns of desmosomal connectivity and motoneuron innervation suggest that these 53 types represent cell types specified by unique development programs and muscle identity genes, as is the case for example in Drosophila larvae (de Joussineau et al., 2012).

To name each muscle cell-type, we adapted available names from the annelid anatomical literature (Bergter et al., 2008; Filippova et al., 2010; Mettam, 2009). However, our study is the highest-resolution whole-body analysis to date, therefore we also had to extend and modify the available nomenclature (Figure 2 and Table 1). 
The majority of muscle types (34 out of 53 types corresponding to 502 out of 852 cells) are in the parapodial appendages and form the parapodial muscle complex (Video 2). The parapodial complex of the first segment in the 3-day-old larva has the same major muscle groups as other segments, but fewer muscle cells and some minor subgroups are missing. The parapodia of this segment will transform into tentacula cirri during cephalic metamorphosis, but at the 3-day-old stage these are bona fide locomotor appendages (Fischer et al., 2010). The 3-day-old larva also has a cryptic segment (segment 0) (Steinmetz et al., 2011), which lacks parapodia and has very few muscle cells.

\section{Reconstruction of the whole-body desmosomal connectome}

To analyse how muscles connect to each other and the rest of the body, we focused on desmosomes. We use a morphological definition of desmosomes as electron-dense structures linking adjacent cells and being anchored to the cytoplasm by intermediate filaments (Figure 1D).

To allow a more comprehensive analysis and annotation, we extended CATMAID with a 'desmosome' connector type (besides synapse and gap junction). Desmosome connectors can be added between two nodes of two skeletons in the tracing tool. These connectors can then be displayed and analysed with other CATMAID widgets, including the Connectivity, the 3D View and the Graph widgets.

We first annotated desmosomes in every 50 layers of the 4,846 layer EM dataset. We then manually surveyed each muscle cell and identified their desmosomal partners that were not connected in the first survey. Desmosomes can span multiple $40 \mathrm{~nm}$ EM layers (up to 15) and are enriched at the ends of muscle cells indicating that these adhesive structures transmit force upon muscle-cell contraction (Figure 1D, Figure 1 - Figure supplement 1). The desmosomal partners of muscle cells include the basal lamina and a diversity of cell types. These are other muscle cells, glia, ciliary band cells, epithelial cells and various follicle cells encircling the chaetae (circumchaetal cells) and the aciculae (circumacicular cells)(Figure 1 - figure supplement 2). In the majority of these desmosomal partner cells but not in the muscle cells - we identified intermediate filaments (Figure 1 - Figure supplement 1). The multi-ciliated cells of the larva also have desmosomal contacts to muscles anchored by intermediate filaments, with the exception of the prototroch (main head ciliary band)(Figure 1 - figure supplement 2).

The full desmosomal connectome is an undirected graph of 2,524 nodes connected by 4,824 edges. 471 of the nodes are fragments of the basal lamina of similar skeleton sizes (see Methods). The largest cluster of interconnected nodes consists of 2,506 nodes.

\section{Local connectivity and modular structure of the desmosomal connectome}

To characterise the structure of the desmosomal network, we first analysed its modularity by the Leiden algorithm, which partitions graphs into well-connected communities (Traag et al., 2019). We detected several dense clusters of nodes or communities in the desmosomal connectome. These communities correspond to anatomical territories in the larval body (Figure 3, Video 3). There are four modules - a left and right ventrolateral and a left and right dorsolateral - consisting of longitudinal muscles spanning all body segments, and associated ciliary band and epithelial cells. Six modules include parapodial muscles and chaetal sac cells, corresponding to the segmental parapodia. One module contains left-right groups of oblique muscles in the second segment, connected at the midline through the basal lamina and axochord (midline muscle)(Lauri et al., 2014). Various head and segment-0 muscles constitute another module (Figure 3, Video 3). 
bioRxiv preprint doi: https://doi.org/10.1101/2021.06.09.447732; this version posted June 10, 2021. The copyright holder for this preprint (which was not certified by peer review) is the author/funder, who has granted bioRxiv a license to display the preprint in perpetuity. It is made available under aCC-BY-NC 4.0 International license.

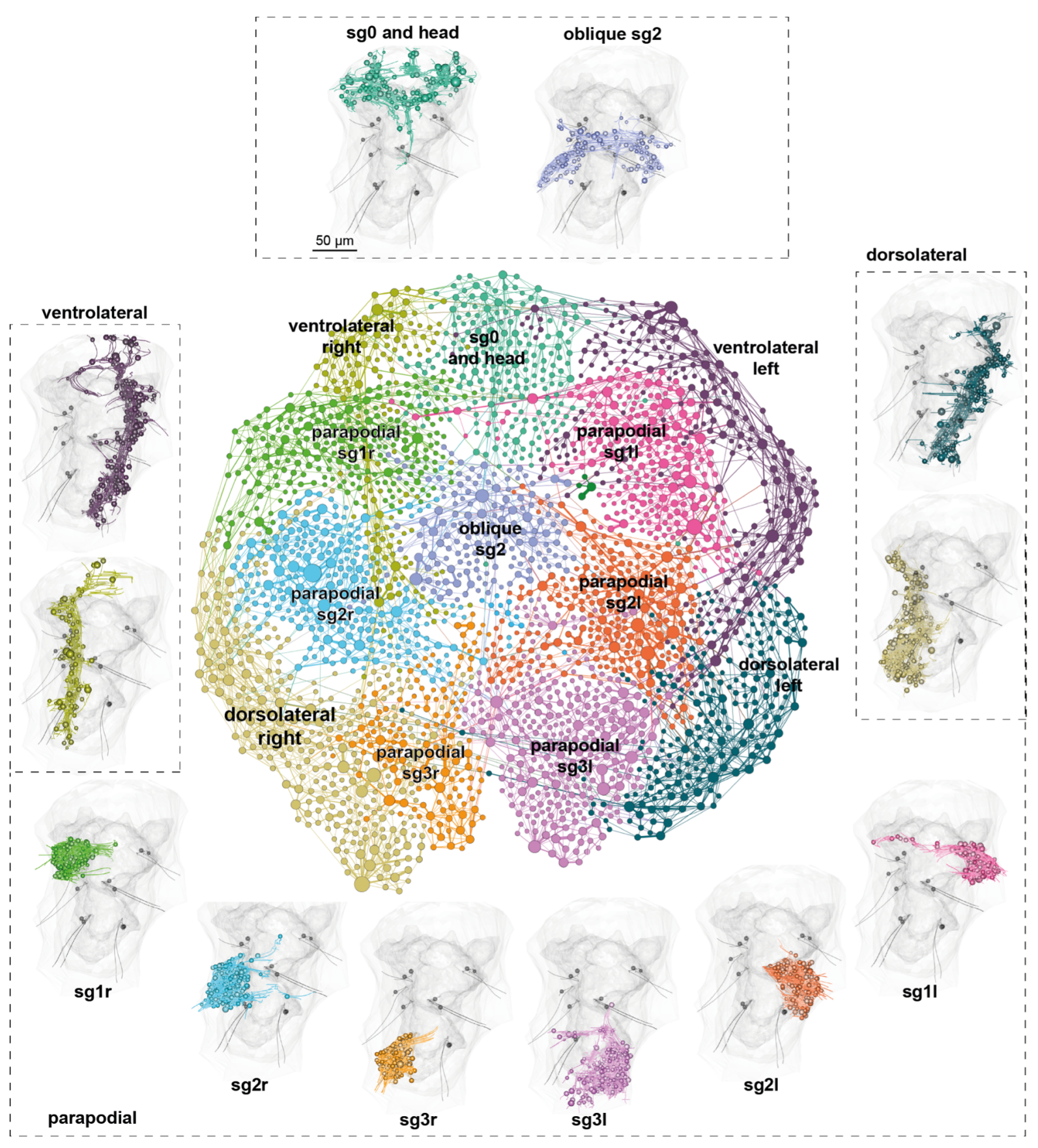

Figure 3. The desmosome connectome of the three-day-old Platynereis larva

Desmosome network coloured by Leiden modules. Nodes represent cells or basal lamina fragments and edges represent desmosomal connections. 3D skeleton reconstructions of the cells of each module are shown. Spheres show positions of nuclei. Grey meshes show the outline of the body and yolk. The 12 aciculae are shown for segmental reference. The layout was computed by a force-fieldbased method. Figure3-source-data 1, a .gephi network file.

To better understand the organisation of the desmosomal network, we compared it to random networks generated under three different models. We used 1,000 each of ErdösRényi, scale-free and preferential-attachment random graphs with the same number of vertices and edges as the desmosomal graph. To obtain weighted graphs, we assigned the 
edge weights from the desmosomal graph to these random graphs. We also generated 1,000 subsamples of the desmosome graph, each with 100 nodes randomly deleted. While all graph types have a similar degree and weighted-degree distribution (Figure 4 A, B), the desmosomal graph stands out as a highly modular and less compact graph with strong local connectivity. This conclusion is supported by several graph measures.

First, we calculated the modularity scores of the graphs (Clauset et al., 2004), following module detection by the Louvain algorithm (Blondel et al., 2008). For both weighted and unweighted graphs, the median modularity scores of the subsampled desmosomal graphs (weighted: 0.88; unweighted: 0.85) are higher than for the Erdős-Rényi (weighted: 0.74; unweighted: 0.54 ), scale-free (weighted: 0.72 ; unweighted: 0.53 ) or preferential-attachment graphs (weighted: 0.84; unweighted: 0.8) (Figure 4).

Next, we compared network statistics describing node clustering, compactness and information flow. While the degree and weighted degree distribution is similar for the four types of graphs, the desmosomal subgraphs stand out with the most cliques, the highest Eigenvalues, largest diameter, and largest mean distance (Figure 4). The number of 3cliques (three fully connected nodes) is highest in the desmosomal graph and this is the only graph with 4-cliques (12 in the original desmosomal graph). The graph diameter (the length of the longest graph geodesic between any two vertices) and the mean of the distances between vertices are measures of graph compactness (Doyle and Graver, 1977). The desmosomal graph with a diameter of 64 and mean distance of 9 is less compact than the preferential-attachment (mean diameter: 15.7; mean distance: 7.8 ), Erdős-Rényi (mean diameter: 12.7; mean distance: 5.9 ) and scale-free (mean diameter: 12.5; mean distance: 5.4) graphs (Figure 4). The largest Eigenvalue of a graph is another key network property influencing dynamic processes (Restrepo et al., 2006). This value is also largest for the desmosomal graph.
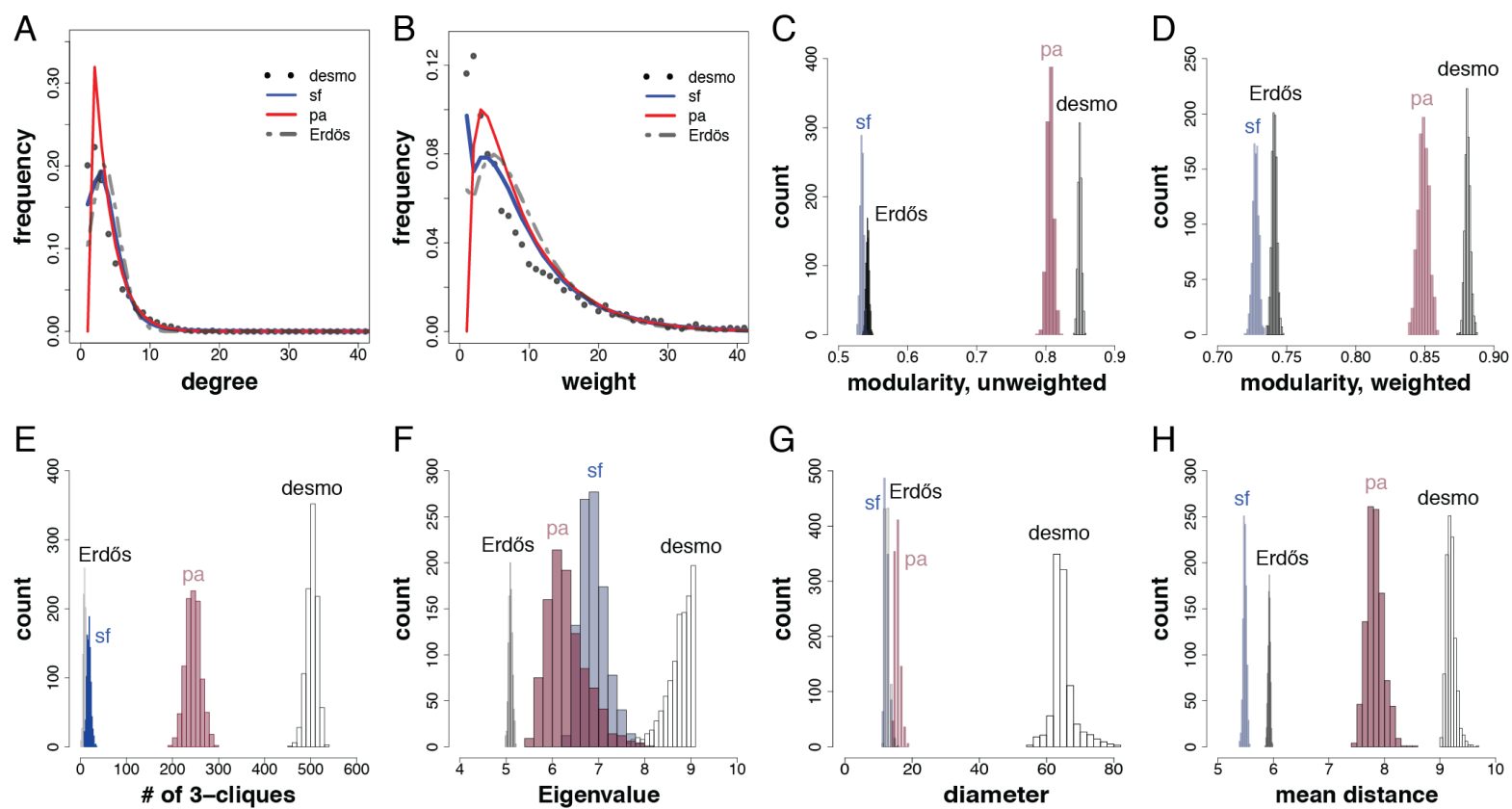

Figure 4. Network statistics of the desmosomal connectome relative to random graphs. (A) Degree distribution and (B) weighted-degree distribution of the desmosomal connectome compared to scale-free (sf), Erdős-Rényi and preferential-attachment (pa) graphs (1,000 graphs each). (C) Modularity scores of 1,000 unweighted scale-free (sf), Erdős-Rényi and preferentialattachment (pa) graphs relative to the unweighted desmosomal graph (1,000 subsamples). (D) 
bioRxiv preprint doi: https://doi.org/10.1101/2021.06.09.447732; this version posted June 10, 2021. The copyright holder for this preprint (which was not certified by peer review) is the author/funder, who has granted bioRxiv a license to display the preprint in perpetuity. It is made available under aCC-BY-NC 4.0 International license.

Modularity scores of 1,000 weighted scale-free (sf), Erdős-Rényi and preferential-attachment (pa) graphs relative to the weighted desmosomal graph (1,000 subsamples). (E) Number of 3-member cliques (triangles), $(F)$ largest Eigenvalues, $(G)$ diameter and $(H)$ mean distance scores of 1,000 scale-free (sf), Erdös-Rényi and preferential-attachment (pa) graphs relative to the desmosomal graph (1,000 subsamples).

Overall, the desmosomal graph stands out as a highly modular graph with a large diameter, large average distance, and high level of local connectivity (cliques). These properties set the desmosomal graph apart from different types of random graphs. We attribute these characteristics to the special organisation of the desmosomal connectome, with all cells only connecting to cells in their immediate neighbourhood forming local cliques, and without longrange connections (e.g. between the left and right body sides).

The tight local connectivity of the desmosomal connectome is also apparent on force-fieldbased layouts of the graph. In force-field-based layouts, an attraction force is applied between connected nodes, together with a node-to-node repulsion and a general gravity force. As a result, more strongly-connected nodes tend to be placed closer to each other.
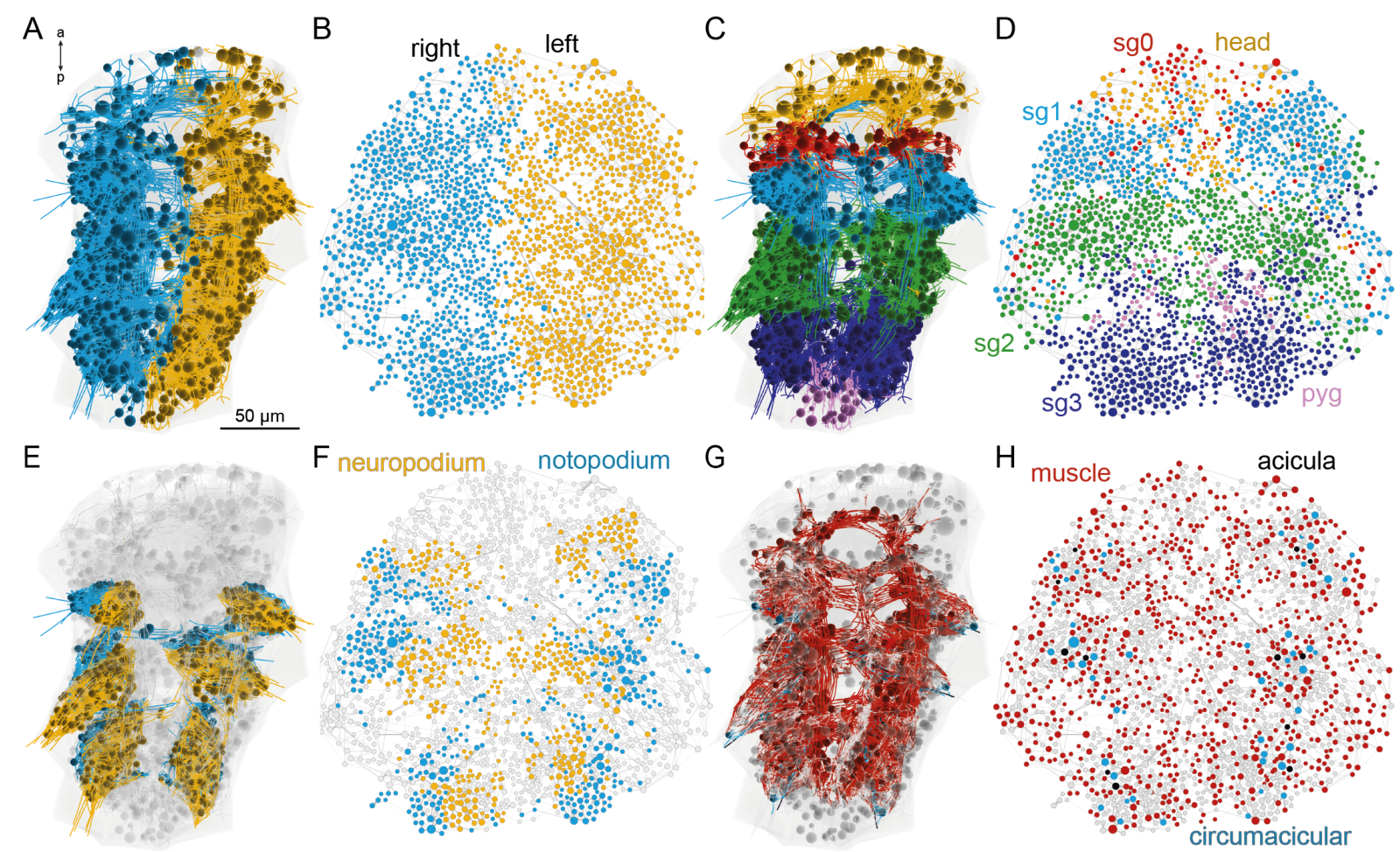

Figure 5. Local connectivity of the desmosomal connectome.

(A) Cells of the desmosomal connectome on the right (cyan) and left (orange) side of the body. (B) The same cells in the force-field-based layout of the graph. (C) Cells of the desmosomal connectome coloured by body region (head, segments $0-3$ and pygidium). (D) The same cells in the force-fieldbased layout of the graph. (E) Cells of the desmosomal connectome in the neuropodia (cyan) and notopodia (orange). (F) The same cells in the force-field-based layout of the graph. (G) Muscle cells (red), aciculae (black) and circumacicular cells (cyan). (H) The same cells in the force-field-based layout of the graph.

To analyse how closely the force-field-based layout of the desmosomal connectome reflects anatomy, we coloured the nodes in the graph based on body regions (Figure 5). In the forcefield layout, nodes are segregated by body side and body segment. Nodes corresponding to the neuropodial (ventral) and notopodial (dorsal) parts of the parapodia also occupy distinct 
domains (Figure 5A-F). The 12 aciculae and the circumacicular cells also occupy positions in the force-field map paralleling their anatomical positions (Figure 5G, $\mathrm{H}$ ). The observation that node positions in the force-field layout of the graph recapitulate the anatomical positions of the nodes reflects the local connectedness (neighbours only) of the desmosomal connectome. This is different from the synaptic connectome where long-range neurite projections can link neurons at two different ends of the body (Verasztó et al., 2020).

\section{High muscle diversity and strong connectivity in the acicular complex}

Next, we queried the desmosomal connectome to better understand the organisation and movement of the annelid larval body. We focused on the parapodial muscle complexes as these contain the largest diversity of muscle types and associated cells (Video 2).

Each parapodial lobe (notopodium and neuropodium) has an internal chitin rod called acicula (Hausen, 2005). Each acicula is ensheathed by acicular follicle cells which contain many intermediate filaments (Figure 1 - figure supplement 2). The parapodial chaetae (bristles) are also ensheathed by four types of follicle cells arranged in a proximo-distal pattern (Figure 6 - figure supplement 4 ). The various follicle cells serve as anchor points for several major muscle groups. Some muscles also directly connect to the aciculoblast, the cell producing the acicula (Figure 6E-G, Figure 1 - figure supplement 1 ).

The aciculae and associated structures, which we refer to as the acicular complex, represent highly connected components in the desmosomal connectome (Figure 6C). The cells with the largest mean degree and weighted degree belong to the acicular complex. When we plot all cells in the desmosomal connectome with a colour transparency inversely proportional to node weight, the acicular complex is highlighted (Figure 6A, B).

We identified 16 muscle types with connections to the aciculae or circumacicular cells (Figure 6G; Figure 6 - figure supplement 1, Figure 6 - figure supplement 2). These include acicular muscles (MUSac), some chaetal muscles (MUSchae) that link the aciculae to the chaetae, and oblique muscles (MUSob) that link the aciculae to the dorsal longitudinal muscles (MUSlong-D).

The notopodial and neuropodical aciculae have distinct muscle partners indicating that these structures could move independently of each other. Two muscles (MUSac-i and MUSacneuDx) link the noto- and neuropodial aciculae within the same parapodium to each other, suggesting force coupling between the two aciculae (Figure 6E, G). We analysed each muscle group for their desmosomal partners and spatial orientation and inferred the possible movements of the aciculae upon their contraction. This revealed several possible acicular movements which we termed abduction, adduction, pistoning, pivoting, jostling and lateral movement (Figure 6 - figure supplement 3 ). In addition, some muscles connect to epithelial cells in the parapodia and through moving these parapodial cells can indirectly also move the aciculae with them (i.e. 'pulled by the skin'; e.g. MUSobP-neuV). 


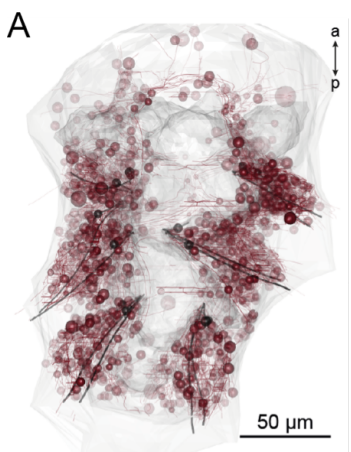

$\mathrm{E}$

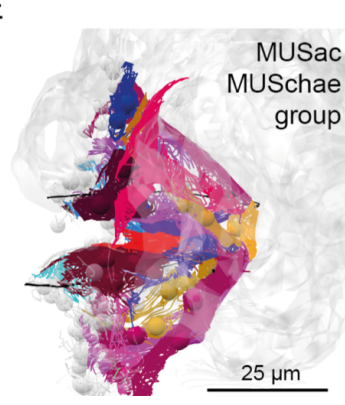

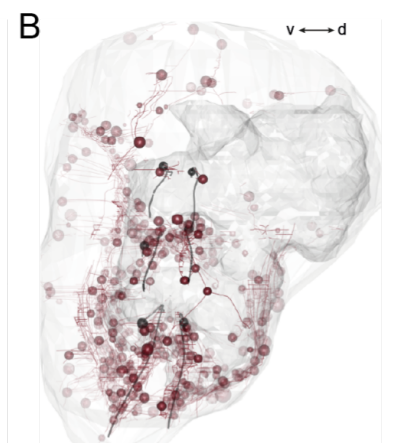

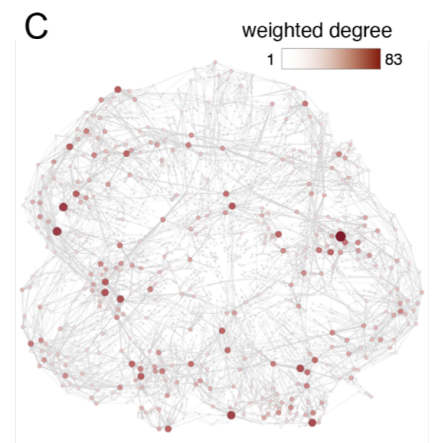

D

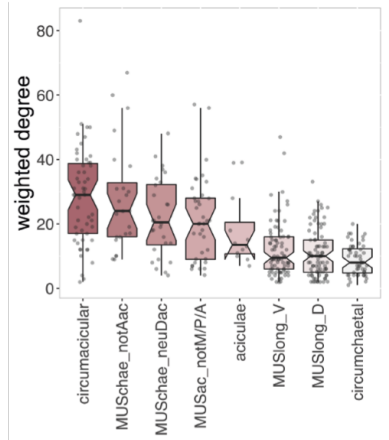

F

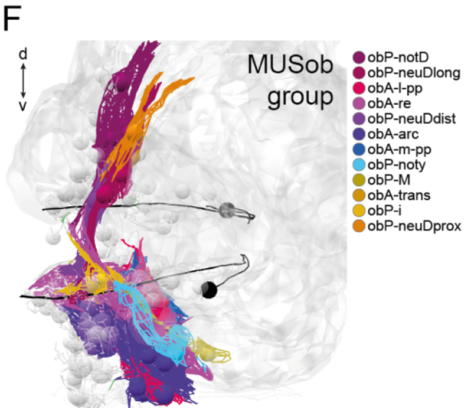

G

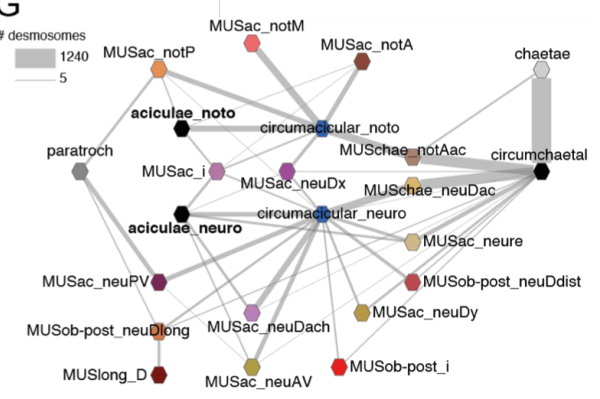

Figure 6. Cell-type diversity and connectivity of the acicular complex.

(A) All cells of the desmosomal connectome shown with a transparency inversely proportional to the cell's weighted degree, ventral and (B) lateral views. (C) The desmosomal connectome with nodecolour intensity and node size proportional to node weighted degree. (D) Weighted degree of the most highly connected cells in the desmosomal connectome, arranged by cell-type. Some cell types are plotted together (MUSac-notM, P and P and the various types of circumchaetal cells). (E) Skeletons of the MUSac and MUSchae muscle cell types that are part of the acicular complex (with desmosomes to circumacicular cells). Posterior view showing neuro- and notopodia in the left side in the second segment. (F) Skeletons of MUSob cell types that are part of the acicular complex (with desmosomes to circumacicular cells). (G) Desmosomal connectivity graph of the acicular complex. Nodes represent groups of cells of the same cell type or cell-type family (circumchaetal). The aciculae and circumacicular cells are separated into neuropodial and notopodial groups. Epithelial cells and the basal lamina are not shown for clarity.

\section{Acicular movements and the unit muscle contractions that drive them}

The desmosomal connectome suggests that each acicula can have complex and extensive movements and the two aciculae can move independently of each other, with some coupling (e.g. through the interacicular muscles). To observe acicular movements in live animals, we first imaged 4-day-old crawling Platynereis larvae with differential interference contrast (DIC) optics.

We used the toolbox DeepLabCut (Mathis et al., 2018) to train a deep residual neural network using sample video frames to learn, track and label 26 body parts of the larvae. This allowed us to track the 12 individual aciculae and their relative angles, both to the body midline (Figure 7A) and to one another (Figure 7B). We found that the notopodial and neuropodial aciculae within one parapodium exhibit differences in movement velocity and angles relative to one another resulting in a range of angles and positions over time (Figure 7, Video 4). During the crawl cycles, the aciculae first draw inwards and forward, diagonally towards the head, then they tilt in a posterior direction, the proximal tip of the neuropodial acicula travelling slightly faster to open up the pair, creating the larger $\left(40-50^{\circ}\right)$ inter-acicular angle (Figure 7E-G). This is followed by a "piston" movement whereby the now parallel aciculae are pushed outwards, then the proximal tips tilt rostrally again, to move the chaetae 
back against the trunk, propelling the animal forward on that side and completing that acicular cycle.

This analysis demonstrates that the acicular pairs can have different relative positions with inter-acicular angles changing between $-25-50^{\circ}$ in a parapodial cycle (Figure 7B, G). These relative changes occur in each segment during crawling, propagating from posterior to anterior through an undulatory gait cycle (Figure 7A).

In order to directly visualise muscle contractions, we next imaged calcium transients in larvae ubiquitously expressing GCaMP6s. Larvae held between a slide and coverslip display spontaneous contractions of different muscle groups ('twitches') revealed by increased GCaMP fluorescence. Simultaneous imaging in the DIC channel allowed us to visualise the movement of the aciculae and parapodia (Figure $7 \mathrm{H}-\mathrm{J}$; Video 5).

The contraction of the posterior ventral neuropodial acicular muscle (MUSac-neuPV) pulls the proximal end of the acicula caudally, inducing an abduction (Figure $7 \mathrm{H}$; Figure 6 - figure supplement $3 \mathrm{C}$ ). These muscles connect to the proximal end of the acicula via circumacicular cells and anchor to the basal lamina, epithelial cells and ciliated cells (paratroch) at their other end (Figure 7K).

The contraction of the posterior ventral neuropodial muscles (MUSobP-neuV) induce an inward movement of the distal tip of the acicula ('flexion', Figure 6 - figure supplement 3B)) leading to the alignment of the parapodia and chaetae with the longitudinal body axis (Figure 7I). These muscles connect to the distal end of the aciculae via circumacicular cells and also connect to epithelial cells in the neuropodium. At their other end, MUSobP-neuV cells are anchored to the basal lamina (Figure $7 \mathrm{~L}$ ).

The MUSac-neuPV cells can contract simultaneously with the parapodial retractor muscles (MUSobA-re), inducing parapodial retraction and a tilt of the aciculae with their proximal tip moving rostrally (Figure $7 \mathrm{~J}$ ). The retractor muscles form desmosomes on EC_circumchaetal and epithelial cells at their distal end in the neuropodium and anchor to midline cells and the basal lamina at their other end (Figure 7M).

We could only observe these spontaneous individual muscle contractions in non-crawling larvae. During a startle response or crawling cycles, many muscles contract rapidly (Bezares-Calderón et al., 2018) and we were not able to spatially and temporally resolve these to individual muscle groups. 
bioRxiv preprint doi: https://doi.org/10.1101/2021.06.09.447732; this version posted June 10, 2021. The copyright holder for this preprint (which was not certified by peer review) is the author/funder, who has granted bioRxiv a license to display the preprint in perpetuity. It is made available under aCC-BY-NC 4.0 International license.

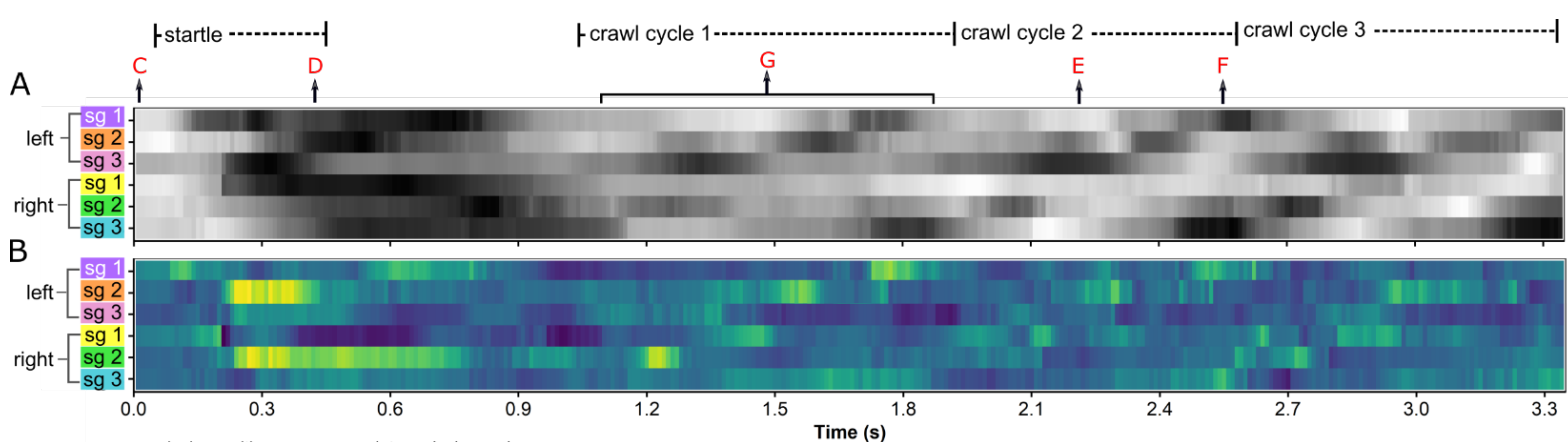

\begin{tabular}{c} 
acicular position \\
\hline $0 \quad-25^{\circ}$ \\
\hline
\end{tabular}

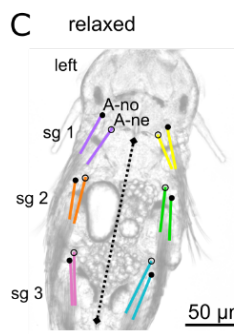

D startled

E crawling

F crawling

$50 \mu \mathrm{m}$
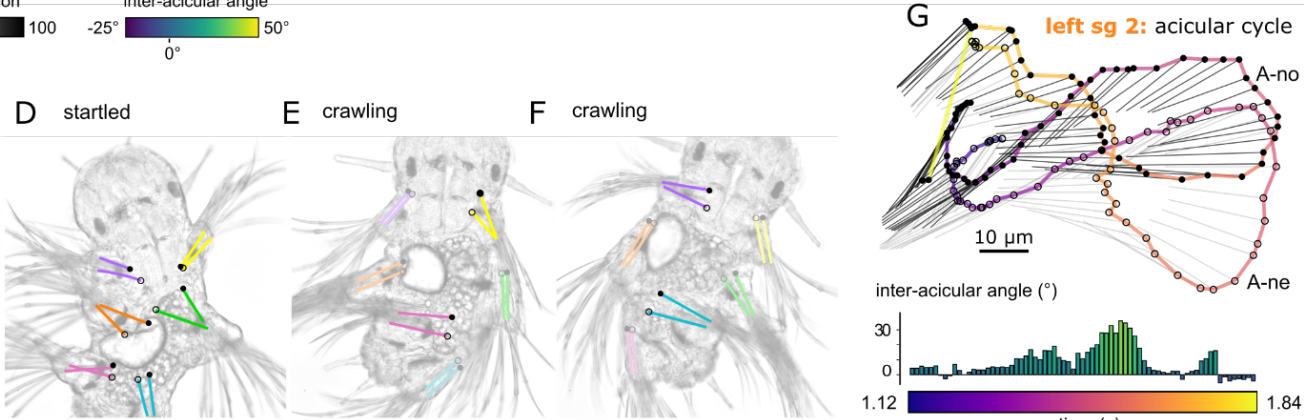

$\mathrm{H}$
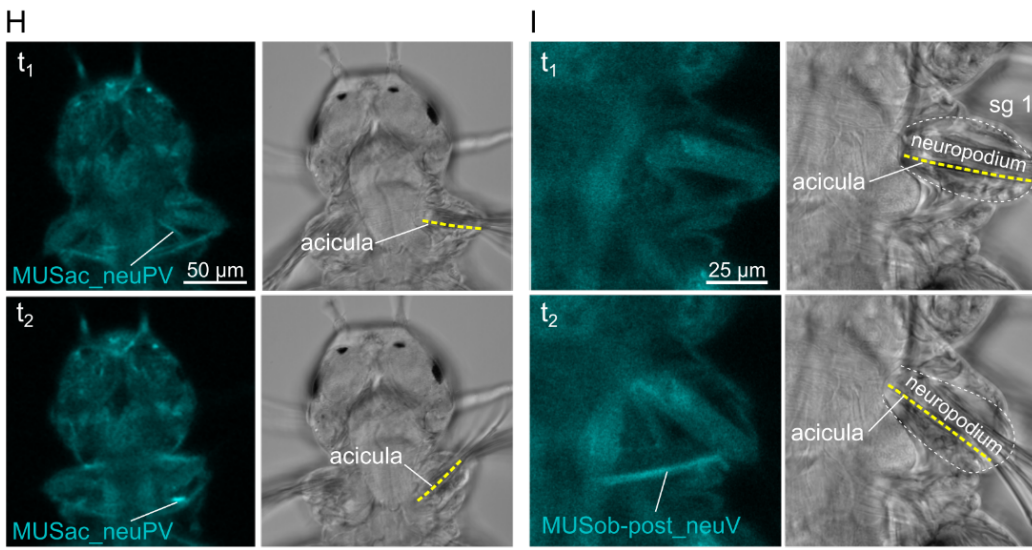

K
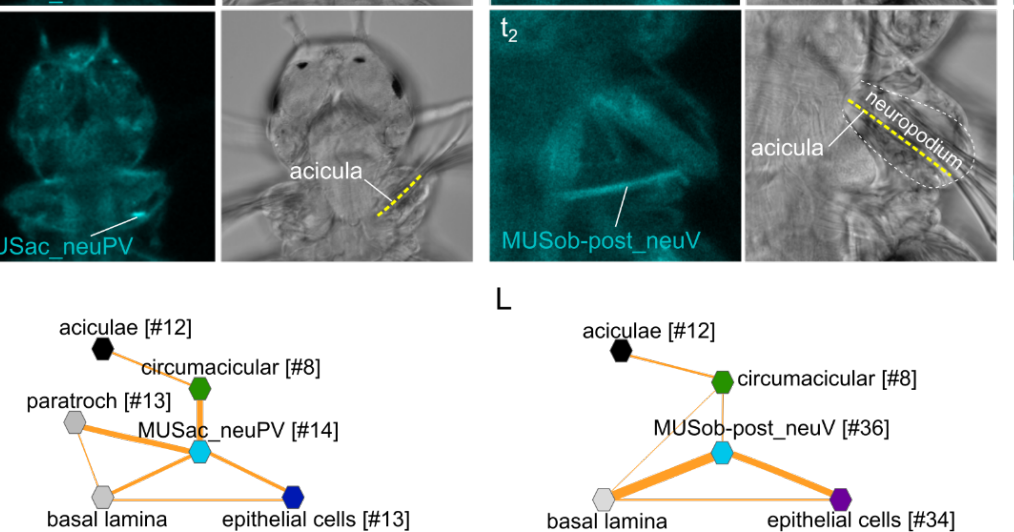

L
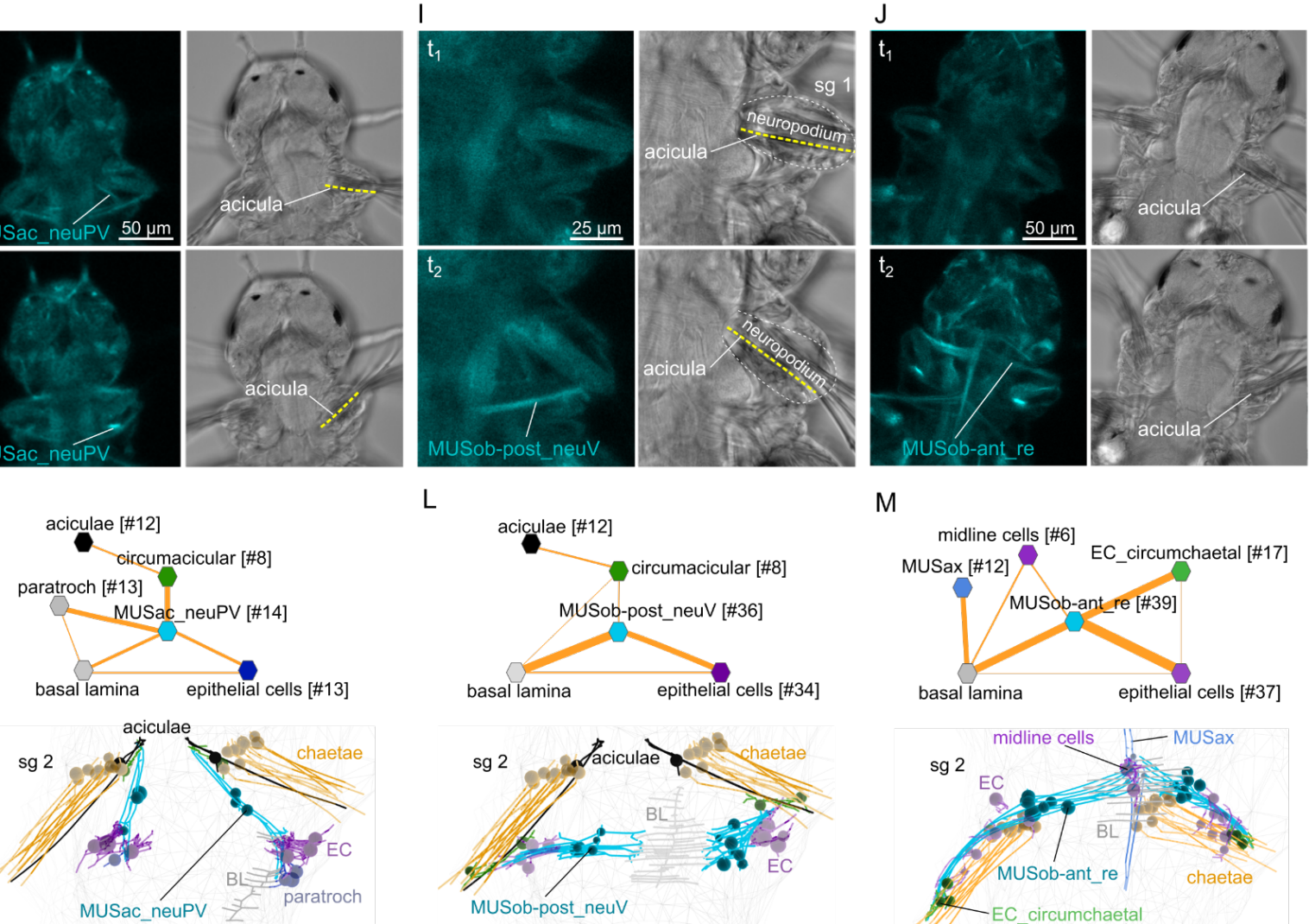

M
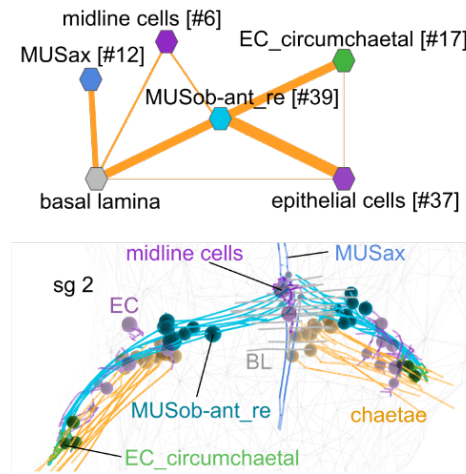

Figure 7. Acicula tracking, muscle contractions and desmosomal connectivity

(A) Acicular position over time in all six parapodia analysed from video tracking data to indicate gait of the larva over time. Angles between the anterior-posterior bodyline connecting the mouth and the hindgut (dotted line, panel C) and each notopodial acicula were normalized (scale 0-100) within each parapodium's angular range of motion. White areas of the heatmap represent aciculae held fully back, close to the trunk. Black areas represent aciculae extended to their extreme forward position. Arrows indicate time points at which panels C-G were taken. (B) Inter-acicular angle between notopodial and neuropodial aciculae over time. Frames of the video sequence are labelled to show (C) the larva relaxed, (D) showing a partial startle response, (E, F) during crawl cycle 2 where opposite acicula 
pairs diverge, extend rostrally and inward towards the trunk, causing the larva to bend left or right. (G) From crawl cycle 1, acicular positions from one example acicular cycle (lasting $720 \mathrm{~ms}$ ) are plotted for the left parapodium in segment 2, as the larva crawls forward. Points mark the proximal tips of the two aciculae, connected by coloured lines to indicate time. Finer light/dark grey straight lines show the relative positions and angles of the distally projecting aciculae. Below, the inter-acicular angles are plotted for the same parapodium over this time period. (H) Live imaging of MUSac-neuPV, (I) MUSobP-neuV and $(\mathrm{J})$ MUSobA-re contraction and neuropodia displacement. In $\mathrm{H}, \mathrm{I}$ and $\mathrm{J}$ the left panel shows the GCaMP6s signal, the right panel shows the DIC channel, the top and bottom panels show two frames from a video $\left(\mathrm{t}_{1}, \mathrm{t}_{2}\right)$. (K) Desmosomal connectivity of MUSac-neuPV. Skeletons of MUSac-neuPV and their desmosomal partners in the 2nd segment. (L) Desmosomal connectivity of MUSobP-neuV. Skeletons of MUSobP-neuV and their desmosomal partners in the 2 nd segment. (M) Desmosomal connectivity of MUSobA-re. Skeletons of MUSobA-re and their desmosomal partners in the 2nd segment. Abbreviations: A-no, notopodial acicula; A-ne, neuropodial acicula; BL, basal lamina; EC, epithelial cell; sg, segment.

\section{Combined analysis of synaptic and desmosomal networks}

The availability of full desmosomal and synaptic connectomes (Verasztó et al., 2020) for the same Platynereis larva allowed us to query how individual motoneurons could influence muscles and associated tissues. Motoneuron activation is expected to induce postsynaptic muscle contraction, which will exert forces on the desmosomal partners of the muscle. By combining desmosomal and synaptic connectomes we can infer the impact of motoneuron activation on tissue movements (Figure 8).

We analysed 12 motoneuron types that are well-developed in the 3-day-old larva (BezaresCalderón et al., 2018; Verasztó et al., 2020). These collectively provide broad innervation across the entire muscle network (Figure $8 \mathrm{~A}$ ). For this analysis we omitted motoneurons which could not be assigned to a well-annotated cell-type category. To analyse the innervation and desmosomal connectivity of individual motoneuron types, we first plotted the synaptic pathways from the 12 motoneuron groups to the 25 out of 53 muscle groups that receive synaptic innervation (Figure $8 \mathrm{~B}$ ). All motoneurons have multiple muscle targets and most muscles receive synapses from more than one motoneuron. 
A

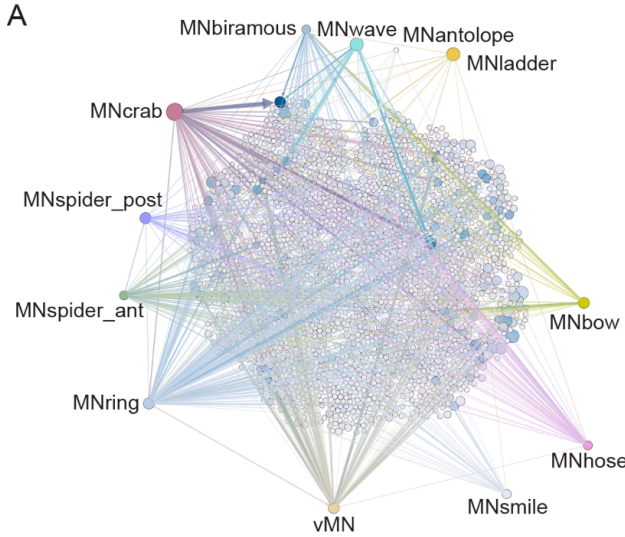

C

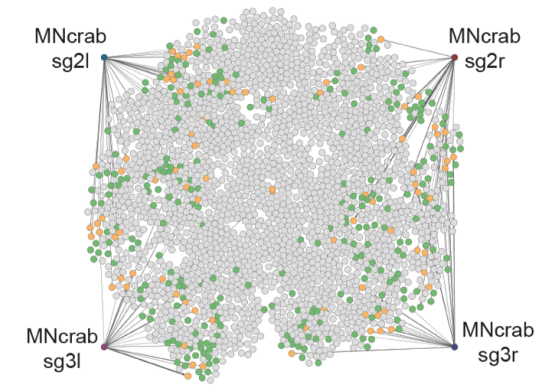

G

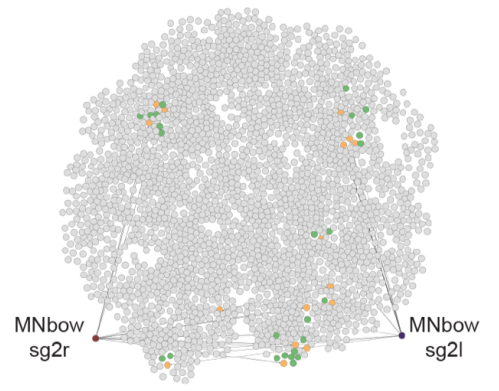

D

$\mathrm{H}$
B
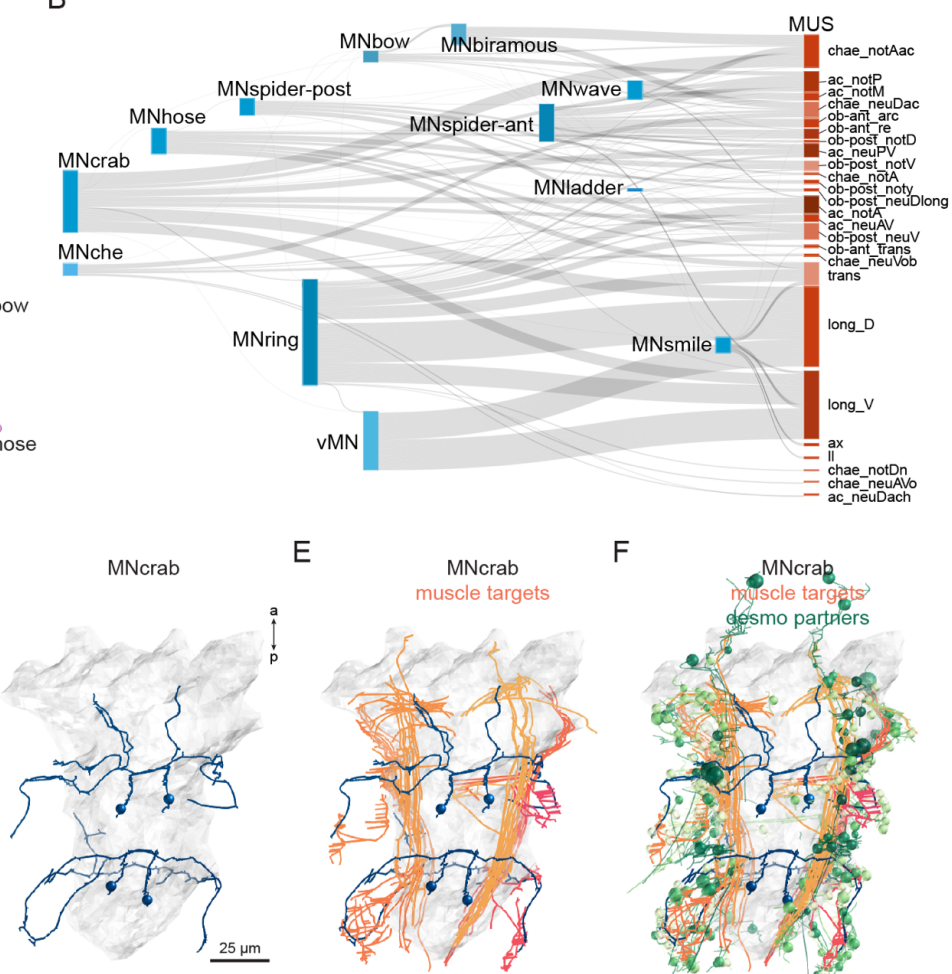

$\mathrm{E}$

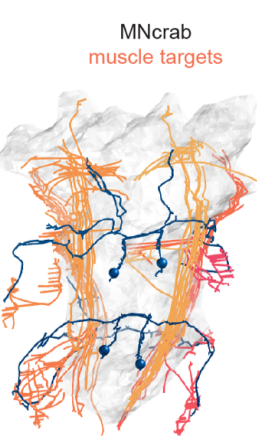

F
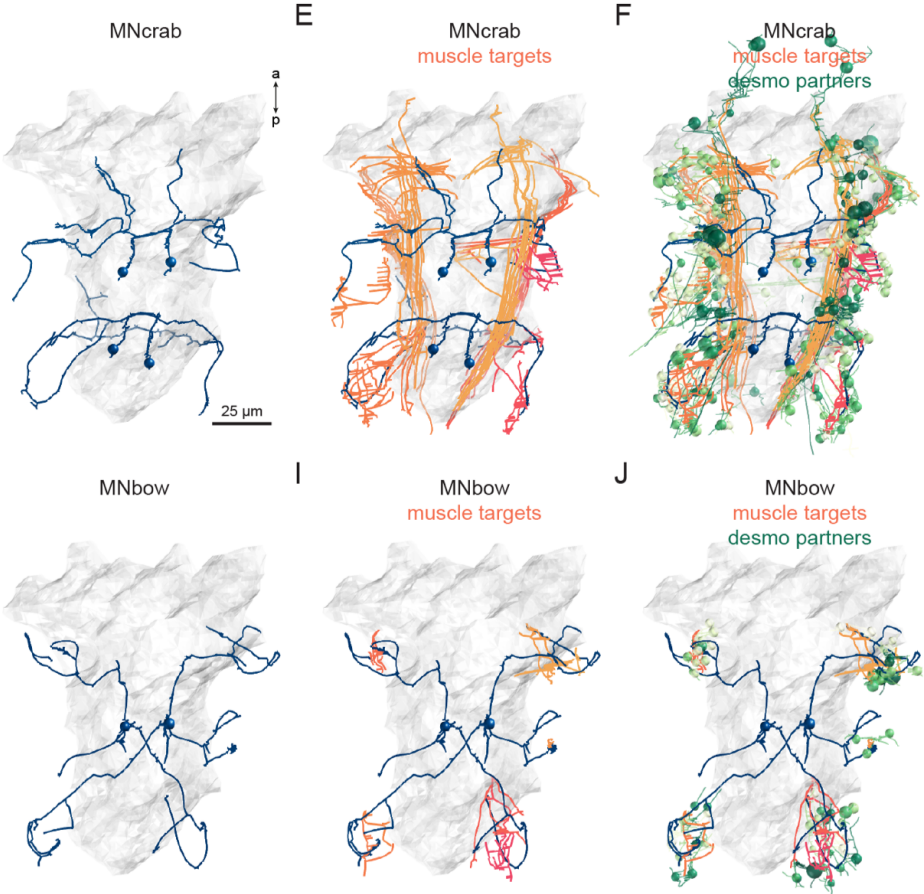

Figure 8. Combining synaptic and desmosomal connectomics

(A) Graph representation of motoneuron synaptic inputs to the desmosomal connectome. The 12 main motoneuron groups are shown. (B) Sankey diagram of the synaptic innervation of muscle types by motoneurons. Motoneurons (blue) and muscles (red) are grouped by cell type. The width of the bands is proportional to the number of synapses from a motoneuron class to a muscle class. (C) MNcrab motoneuron synaptic inputs to muscle cells (orange) in the desmosomal connectome and the desmosomal partners of these muscle cells (green). (D) The four MNcrab motoneurons. (E) The postsynaptic muscle partners (shades of red) of the MNcrab neurons (blue). (F) The postsynaptic muscle partners (shades of red) of the MNcrab neurons (blue) and the desmosomal partners of the innervated muscles (shades of green). (G) MNbow motoneuron synaptic inputs to muscle cells (orange) in the desmosomal connectome and the desmosomal partners of these muscle cells (green). (H) The two MNbow motoneurons. (I) The postsynaptic muscle partners (shades of red) of the MNcrab neurons (blue). (J) The postsynaptic muscle partners (shades of red) of the MNcrab neurons (blue) and the desmosomal partners of the innervated muscles (shades of green). In D-F and $\mathrm{H}-\mathrm{J}$ the yolk outline is shown in grey for reference. In A, C and $G$ the desmosomal links are not shown for clarity. The node layout is the same as in Figures 3 and 5. 
bioRxiv preprint doi: https://doi.org/10.1101/2021.06.09.447732; this version posted June 10, 2021. The copyright holder for this preprint (which was not certified by peer review) is the author/funder, who has granted bioRxiv a license to display the preprint in perpetuity. It is made available under aCC-BY-NC 4.0 International license.

To characterise the tissue range of each motoneuron type, we first queried their postsynaptic muscle partners in the synaptic connectome and then retrieved all desmosomal partners of these muscles (Figure 8B). We derived such combined synaptic-desmosomal graphs for all 12 motoneuron classes (Figure 9). Plotting the skeleton reconstructions of these cells highlights the extent of the tissue under the influence of a motoneuron class (Figure 8C-J and Figure 8 - figure supplement 1 )(Video 6). The most highly connected muscle cell type in the parapodial complex (MUSchae-notAac) forms desmosomes on 9 distinct non-muscle cell types (Figure 8 - figure supplement 3 ). When the muscle contracts, all these cells are expected to experience the forces of the contraction.

A
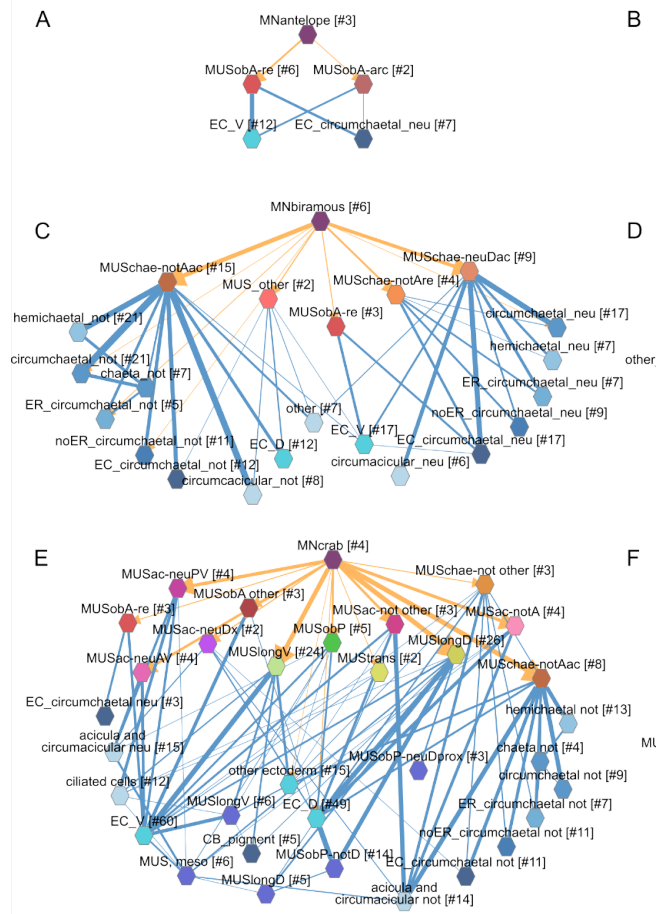

G
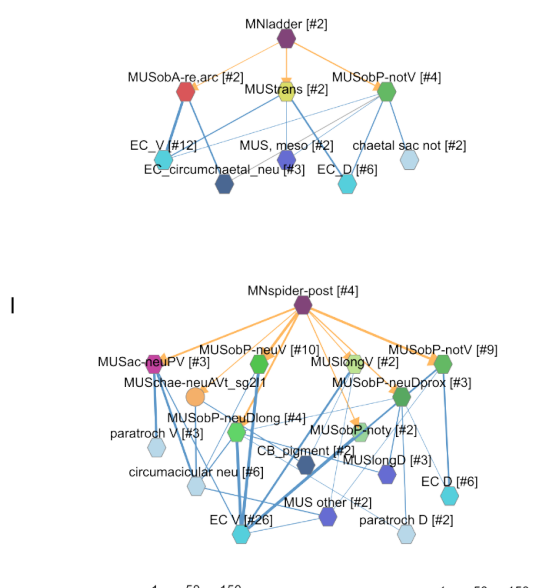

Figure 9. Combined synaptic-desmosomal graphs of motoneurons

Synaptic connections (orange arrows) of motoneuron classes to muscles and desmosomal links (blue edges) of the innervated muscle cells.
B
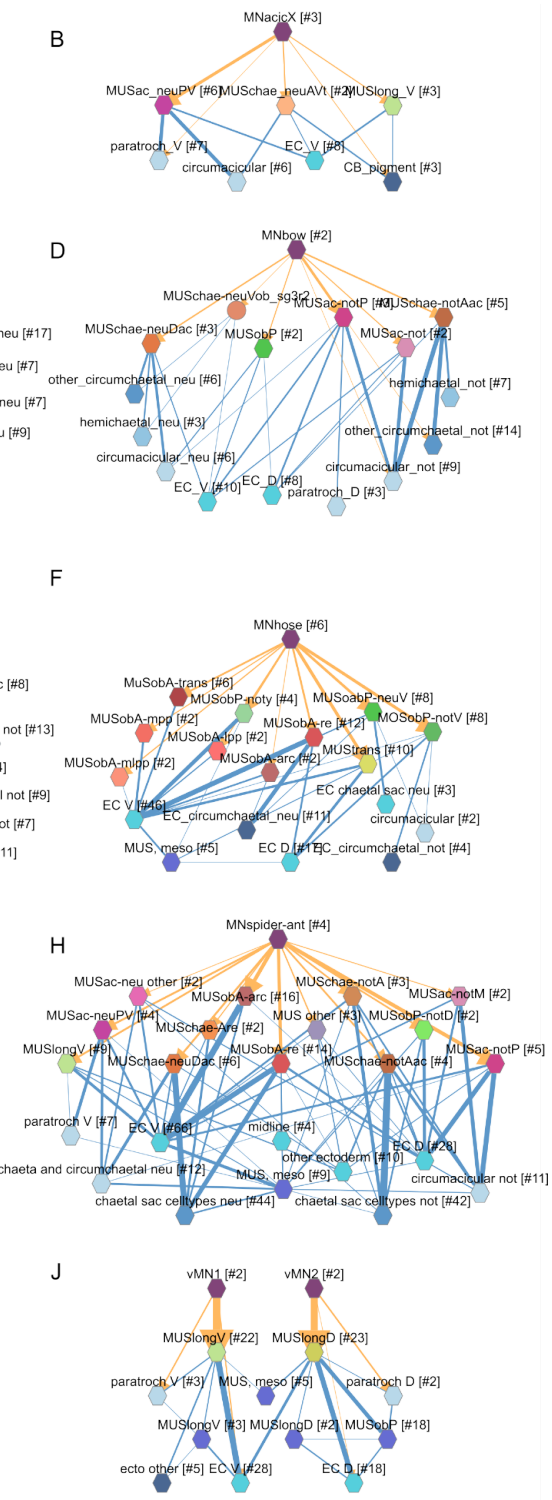

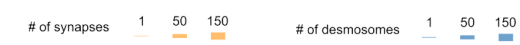

of motoneuron classes to muscles 
Next, we focused on the acicular muscle complex and highlighted each muscle and their desmosomal partners that are under the influence of a motoneuron class. There are eight motoneuron classes that innervate the parapodial complex (MNcrab, MNbiramous, MNwave, MNspider-ant, MNspider-post, MNhose, MNchae and MNring). Each of these innervates a unique combination of muscle targets - not a single muscle type (Figure 10). This suggests the concerted activity of anatomically distinct muscle types during the parapodial crawl cycle and other appendage movements.

A

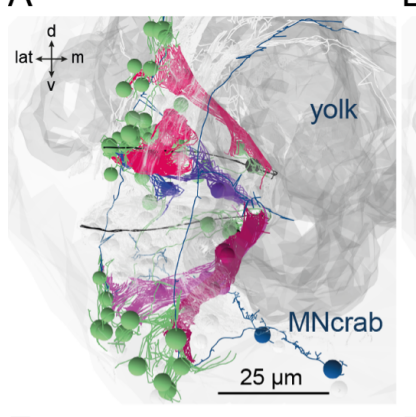

E

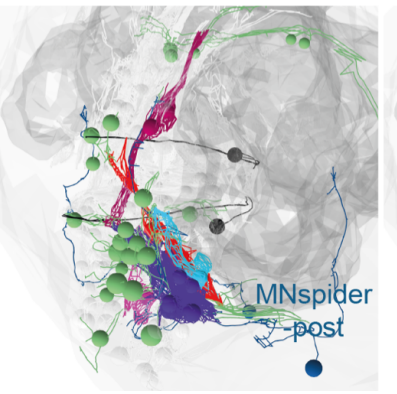

B

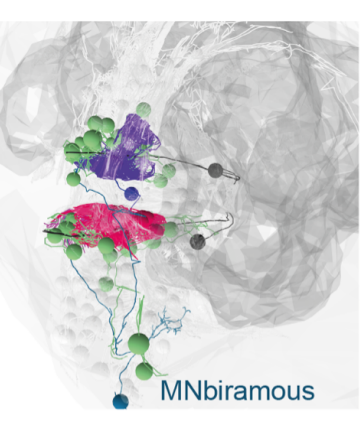

$\mathrm{F}$

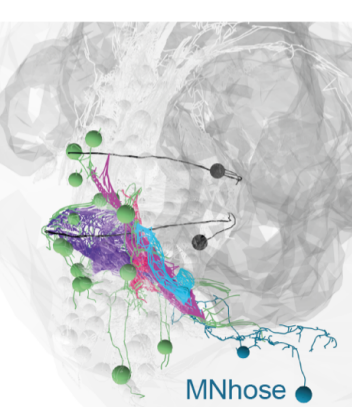

C

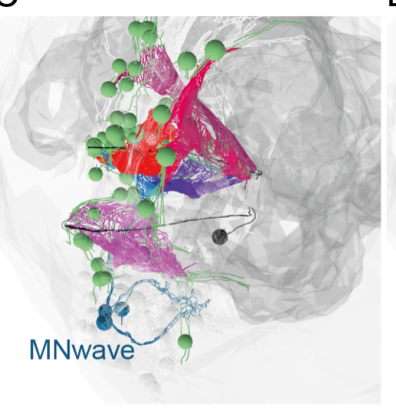

G

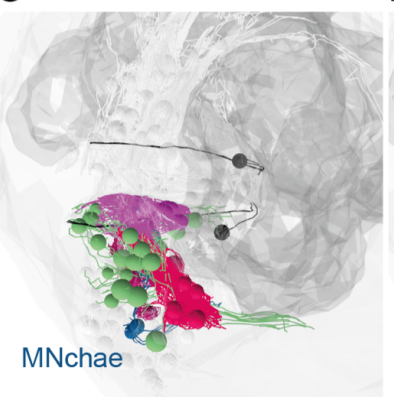

$\mathrm{D}$

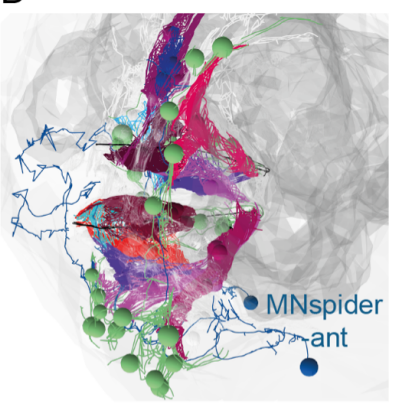

$\mathrm{H}$

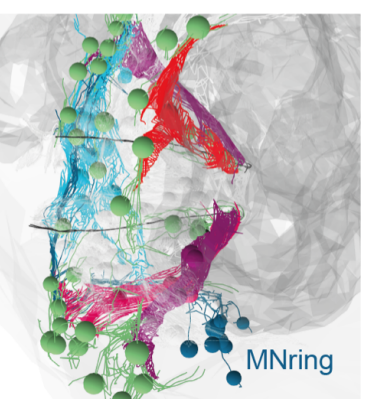

Figure 10. Postsynaptic muscle targets in the parapodial complex of different motoneurons. Postsynaptic muscle targets (red-purple) within the parapodial complex of (A) MNcrab, (B) MNbiramous, (C) MNwave, (D) MNspider-ant, (E) MNspider-post, (F) MNhose, (G) MNchae and (H) MNring motoneurons. The desmosomal partners of the innervated muscles are also shown (green). Only the muscles in the left parapodium of segment 2 and the motoneurons innervating this parapodium are shown.

\section{Discussion}

Here we reconstructed the somatic musculature and attached tissues in the nereid larva and showed how adhesion networks can be analysed for an entire body. We call this approach desmosomal connectomics, where the desmosomal connectome comprises all cells and extracellular structures (basal lamina, aciculae, chaeta) and their desmosomal connections. Our reconstructions revealed the high diversity of muscle-cell types in the larva. The complexity of the nereid musculature contrasts to the relatively simple muscle architecture in the nematode Caenorhabditis elegans and the tadpole larva of the tunicate Ciona intestinalis. The $C$. elegans hermaphrodite has 95 body wall muscles all with a similar rhomboid shape (Gieseler et al., 2017). In the $C$. intestinalis larva, there are 36 muscle cells of 10 types (Nakamura et al., 2012). In contrast, the 3-day-old nereid larva has 853 muscle cells belonging to 53 types. 
A large number of muscles engage in the movement of the acicular complex of the parapodia. This suggests that the diversity of nereid somatic muscles is due to the presence of an endoskeleton. Polychaete annelids are the only animals outside the tetrapods that have trunk appendages rigidified by an endoskeleton. Aciculae appear in some stem-annelid fossils from the lower Cambrian (Liu et al., 2015) indicating the deep ancestry of these structures, predating tetrapod limbs. In contrast to tetrapod limb bones, the aciculae are independent skeletal elements without joints. Their function is nevertheless similar in that they provide attachment sites for limb muscles and rigidity in the appendages during movement. In each parapodium, the two aciculae are moved by unique and shared sets of muscles and change their relative angle within a crawling cycle.

Beyond the complexity of the somatic musculature, our global analysis also revealed the diversity of desmosomal partners of muscle cells. These comprise over 10 different cell types, ranging from epithelial and various follicle cells through pigment cells to ciliary band cells. The stereotypy of the desmosomal connections across segments and body sides suggests that - analogous to the synaptic connectome - the desmosomal connectome develops through a precisely specified connectivity code between cell types. Some of these connections have a clear functional relevance, as the attachment of muscles to movable chitin structures. Others are more intriguing, such as the connections to locomotor ciliary cells. These may be due to proximity and the need for muscles to attach to something, alternatively, may mediate hitherto unexplored mechanistic interactions between muscular and ciliary locomotion or represent signalling connections (Green and Gaudry, 2000). The whole-body desmosomal connectome described here in combination with the synaptic connectome from the same volume (Verasztó et al., 2020) provide the foundation for understanding locomotor control in the nereid larva. In a crawling larva, a large number of muscles is recruited in a precise temporal order in each limb to execute a full appendage cycle. The limb movements are organised into a gait sequence, starting from the posteriormost segment (Figure 7). Our imaging of spontaneous muscle twitches (Figure 8), prediction of unit acicular movements (Figure 6 - figure supplement 3 ) and analysis of motoneuron innervation (Figure 9) are the first steps towards understanding parapodial movements and their neuronal control. The availability of a laboratory culture, whole-body connectome and a growing repertoire of genetic tools make the nereid larva a promising experimental system for the in depth analysis of locomotor control.

We argue that in Platynereis as well as in other animals, understanding and accurately modelling locomotion will not only require analysing nervous activity and synaptic contacts, but also comprehensive maps of the adhesive networks of muscle systems.

\section{Methods}

\section{Cell reconstruction and annotations}

We reconstructed all muscle and other cells by skeletonisation in CATMAID (Saalfeld et al., 2009). For each cell, we marked the position of the soma. Muscle cells were identified by the presence of striated actin-myosin filaments. Developing muscles with a morphology similar to differentiated muscle cells but lacking actin-myosin fibres were not included in the desmosome network. Short segments of the basal lamina were also reconstructed as skeletons. Each basal lamina segment has at least two desmosomes and its cable length does not exceed $63,700 \mathrm{~nm}$. Using such relatively short and often branched fragments allowed us to only focus on basal-lamina-mediated connections for nearby cells. The basal lamina spans the entire body and runs between the ectoderm and the mesoderm. When we 
consider the basal lamina as one giant skeleton, it is the highest-ranking node in the network and distorts the spatial layout (not shown).

We classified muscle and other cells into cell types based on their position, morphology, ultrastructural features, desmosomal connectivity and synaptic inputs. The complete classification of neuronal and non-neuronal cells for the same volume is described in (Verasztó et al., 2020).

We annotated all cells by their cell type categories (Supplemental table 1), the position of the soma in a body segment (episphere, segment_0, segment_1, segment_2, segment_3, pygidium), and body side (left_side, right_side), and specific ultrastructural features (e.g. intermediate filaments, villi, dense cored vesicles, etc.).

\section{Connectome reconstruction}

In order to mark muscle attachment sites, we added a new connector type to CATMAID: the desmosome connector. Within CATMAID, neurons link to each other through so-called connector nodes. Each one acts as a hub so that two or more neurons can connect to each other at the same location. The type of such a link is determined by the relation attached to it. For desmosome connectors, two neurons are allowed to connect to a connector node using the desmosome_withrelation. We also updated various APIs and CATMAID front-end tools to support the new desmosome connector type.

Desmosomes can be identified as dark electron dense plaques on cell membranes with a lighter electron dense extracellular core area (desmoglea). Intracellular intermediate filaments frequently connect to the electron dense desmosome plaques. Hemidesmosomes were marked as connections between a cell and the basal lamina skeleton. To sample desmosomes across the body, we first sampled every $50^{\text {th }}$ layer in the 4846 -layer EM volume and marked every desmosome and hemidesmosome in those layers. We then identified all muscle cells without a desmosome from this first sampling and individually identified and marked their desmosomes.

The desmosome connectome was defined by selecting all muscle cells and adding all cells and basal lamina they connect to via desmosomes. All of these cells were then selected and everything connected to them via desmosomes was added. This process was repeated until no new cells were identified. Unconnected nodes and small local clusters were removed. These were mostly single nodes representing developing muscles (mostly pharyngeal) with very few desmosomes. The only cluster which is not connected to the main cluster is based around two smooth muscle cells in the head. The final network (CATMAID annotation: desmosome_connectome) contains 2,532 skeletons of which 2,016 are cells with a tagged soma.

\section{Network analyses}

We exported the desmosomal network from the CATMAID Graph widget as a .gml file and imported it into Gephi for further analysis and visualisation. The network was also analysed in R. For some visualisation steps (Figure 5), we first carried out a force-field clustering on Gephi and exported the graph in this force-field based layout as a graphml file. The graph was then reimported into the CATMAID Graph widget and coloured based on the CATMAID annotations.

Force field clustering was carried out with the Force Atlas tool in Gephi (0.9.2) The inertia was set to 0.1 , repulsion strength was 35 , attraction strength was 10 , maximum displacement was 5 , gravity was 50 , speed was 5 and the 'attraction distribution' option was selected. The 'auto stabilise function' was off. Towards the end of the clustering the 'adjust 
by sizes' option was also selected. To prevent node overlap, we then run the 'Noverlap' function.

To detect modules, we used the Leiden algorithm as implemented in Gephi with the 'modularity' quality function, a resolution of $0.3,1000$ iterations, 150 restarts, a random seed of 11 , and the 'use edge weights' option on.

To calculate the modularity of the 1,000 Erdős-Rényi, 1,000 scale-free graphs and 1,000 subsampled desmosome graphs, we used the Louvain algorithm for speed (cluster_louvain, as implemented in the iGraph package, version 1.2.5).

All R code has been deposited to github (https://github.com/JekelyLab/Jasek et al, commit: b86f57d).

\section{Anatomical visualisation}

To visualise skeletons and soma positions in 3D, we used either the CATMAID 3D view widget or the Natverse package (Bates et al., 2020) in R with the rgl plot engine.

Videos were either generated in CATMAID or in Fiji, from individual images exported as png files from R. From CATMAID, we exported the videos as. WebM files from the 3D View widget (Export $->$ Animation). WebM files were converted to mp4 files with ffmpeg with the command: ffmpeg -i infile.webm -f mp4 -vcodec h264 outfile.mp4.

\section{Live imaging}

To image muscle contractions, we used larvae expressing GCaMP6s. Zygotes were microinjected with GCaMP6s mRNA as described (Bezares-Calderón et al., 2018). For imaging, we used a Zeiss LSM 880 confocal microscope with a 40x C-Apochromat 40x/1.2 W Korr FCS M27 water-immersion objective.

Crawling 5-day-old larvae were imaged with a Leica DMi8 microscope with DIC optics and a V1212 phantom vision research camera.

\section{Tracking of acicular movements}

We used the toolbox DeepLabCut (Mathis et al., 2018) to train a deep residual neural network (ResNet-50). In 30 sample video frames, we manually labelled 26 body parts of the larva, including the end of the pharynx and the developing proctodeum (posterior gut lumen), in addition to two points along the larva's 12 aciculae; the proximal tip and a more distal point. The network ran 150,000 training iterations before we evaluated it and removed outliers, making corrections for refinement. Afterwards, we merged and retrained the network to improve tracking accuracy. Two high-speed video sequences were then analysed by the trained network using this DeepLabCut toolbox. Video 1 incorporated a partial startle response to physical disturbance and three complete crawling cycles. Video 2 featured a complete startle response. We then created videos with labelled body parts using the filtered predictions of the network, which appear as coloured dots, some of which (e.g. proximal and distal points of the same aciula) are connected by black "skeleton" lines. A line also connects the pharynx and proctodeum, providing a longitudinal bodyline axis (see also dotted line in Figure $7 \mathrm{C}$ ). Once satisfied with the accuracy of the tracking, we analysed the xy positions and relative angles of aciculae from the tracking data (Figure 7 source data 1). To reveal patterns of gait as the larva crawled, the angles between each notopodial acicula and the larva's longitudinal axis were normalised (scale 0-100) within each acicula's own extremes of movement. This normalisation was necessary due to the different angular placements and ranges of motion between the parapodia along the segments of the body. In addition, we 
bioRxiv preprint doi: https://doi.org/10.1101/2021.06.09.447732; this version posted June 10,2021 . The copyright holder for this preprint (which was not certified by peer review) is the author/funder, who has granted bioRxiv a license to display the preprint in perpetuity. It is made available under aCC-BY-NC 4.0 International license.

calculated the angles between acicular pairs within the same parapodium to assess the degree to which they remain parallel and at which times they diverge or move independently.

\section{Acknowledgements}

We thank Liz Williams and members of the Jékely lab for comments on the manuscript. We thank Luis A. Bezares-Calderón for providing GCaMP larvae. We also thank Kirsty Wan for helping with the fast DIC imaging of acicular movements. This research was supported by the FP7-PEOPLE-2012-ITN grant no. 317172 "NEPTUNE". This research was funded by the Wellcome Trust Investigator Award 214337/Z/18/Z.

Table 1. Muscle cell types

\begin{tabular}{|c|c|c|c|c|c|c|}
\hline & & $\begin{array}{l}\text { Anatomical } \\
\text { name and } \\
\text { CATMAID } \\
\text { annotation }\end{array}$ & $\begin{array}{l}\text { Example } \\
\text { CATMAID } \\
\text { neuron name } \\
\text { (example) }\end{array}$ & $\begin{array}{l}\text { Number } \\
\text { of cells } \\
\text { (per } \\
\text { segment } \\
\text { [sg] and } \\
\text { body side) }\end{array}$ & $\begin{array}{l}\text { Desmosomal } \\
\text { connections to }\end{array}$ & $\begin{array}{l}\text { Synaptic } \\
\text { connectio } \\
\text { ns from } \\
\text { (>3 } \\
\text { synapses) }\end{array}$ \\
\hline \multirow[t]{6}{*}{$\begin{array}{l}\text { Acicular } \\
\text { muscle } \\
\text { (MUSac) }\end{array}$} & \multirow[t]{3}{*}{ Notopodial } & $\begin{array}{l}\text { anterior } \\
\text { notopodial } \\
\text { acicular muscle }\end{array}$ & MUSac-notA & $\begin{array}{l}\text { sg1: } 21,2 r \\
\text { sg2: } 21,2 r \\
\text { sg3: } 21,2 r\end{array}$ & $\begin{array}{l}\text { Proximal base of } \\
\text { notopodial } \\
\text { acicula; } \\
\text { notopodial ECs }\end{array}$ & $\begin{array}{l}\text { MNring; } \\
\text { MNcrab; } \\
\text { MNwave; } \\
\text { MNantacic }\end{array}$ \\
\hline & & $\begin{array}{l}\text { posterior } \\
\text { notopodial } \\
\text { acicular muscle }\end{array}$ & MUSac-notP & $\begin{array}{l}\text { sg1: } 2 l, 2 r \\
\text { sg2: 2l, } 2 r \\
\text { sg3: } 21,2 r\end{array}$ & $\begin{array}{l}\text { Proximal base of } \\
\text { notopodial } \\
\text { acicula; septal } \\
\text { ECs and dorsal } \\
\text { paratroch }\end{array}$ & $\begin{array}{l}\text { MNacic; } \\
\text { MNwave; } \\
\text { MNbow; } \\
\text { MNspider- } \\
\text { ant; } \\
\text { MNcrab; } \\
\text { MNperif }\end{array}$ \\
\hline & & $\begin{array}{l}\text { middle notopodial } \\
\text { acicular muscle }\end{array}$ & MUSac-notM & $\begin{array}{l}\text { sg1: } 21,2 r \\
\text { sg2: } 21,2 r \\
\text { sg3: } 21,2 r\end{array}$ & $\begin{array}{l}\text { Proximal base of } \\
\text { notopodial } \\
\text { acicula; } \\
\text { parapodial ECs }\end{array}$ & $\begin{array}{l}\text { MNwave; } \\
\text { MNacic }\end{array}$ \\
\hline & \multirow[t]{3}{*}{ Neuropodial } & $\begin{array}{l}\text { anterior ventral } \\
\text { neuropodial } \\
\text { acicular muscle }\end{array}$ & MUSac-neuAV & $\begin{array}{l}\text { sg1: } 21,2 r \\
\text { sg2: 3l, 3r } \\
\text { sg3: } 31,3 r\end{array}$ & $\begin{array}{l}\text { Proximal base of } \\
\text { neuropodial } \\
\text { acicula; epithelial } \\
\text { cells near } \\
\text { ventrolateral } \\
\text { muscles }\end{array}$ & $\begin{array}{l}\text { MNcrab; } \\
\text { MNring }\end{array}$ \\
\hline & & $\begin{array}{l}\text { posterior dorsal } \\
\text { neuropodial } \\
\text { acicular muscle }\end{array}$ & MUSac-neuPD & $\begin{array}{l}\text { sg1: 3l, 3r } \\
\text { sg2: 3l, 3r } \\
\text { sg3: 3l, } 3 r\end{array}$ & $\begin{array}{l}\text { Proximal base of } \\
\text { neuropodial } \\
\text { acicula; dorsal } \\
\text { ECs and } \\
\text { notopodial EC } \\
\text { circumchaetal and } \\
\text { distal notopodial } \\
\text { acicula (1) and } \\
\text { dorsal paratroch } \\
\text { (2) }\end{array}$ & $\begin{array}{l}\text { MNarm; } \\
\text { sparse } \\
\text { various } \\
\text { others }\end{array}$ \\
\hline & & $\begin{array}{l}\text { posterior ventral } \\
\text { neuropodial } \\
\text { acicular muscle }\end{array}$ & MUSac-neuPV & $\begin{array}{l}\text { sg1: } 21,2 r \\
\text { sg2: } 31,3 r \\
\text { sg3: } 21,2 r\end{array}$ & $\begin{array}{l}\text { Proximal base of } \\
\text { neuropodial } \\
\text { acicula; ventral } \\
\text { paratroch and } \\
\text { ECs around it }\end{array}$ & $\begin{array}{l}\text { MNcrab; } \\
\text { MNacicX; } \\
\text { MNspider- } \\
\text { post; } \\
\text { MNring; } \\
\text { MNperifac; } \\
\text { MNspider- }\end{array}$ \\
\hline
\end{tabular}


bioRxiv preprint doi: https://doi.org/10.1101/2021.06.09.447732; this version posted June 10, 2021. The copyright holder for this preprint (which was not certified by peer review) is the author/funder, who has granted bioRxiv a license to display the preprint in perpetuity. It is made available under aCC-BY-NC 4.0 International license.

\begin{tabular}{|c|c|c|c|c|c|c|}
\hline & & & & & & $\begin{array}{l}\text { ant; } \\
\text { MNpostv }\end{array}$ \\
\hline & & neuropodial $Y$ & MUSac-neuDy & $\begin{array}{l}\text { sg1: 0l, } 0 \mathrm{r} \\
\text { sg2: } 1 \mathrm{l}, 1 \mathrm{r} \\
\text { sg3: } 1 \mathrm{l}, 1 \mathrm{r}\end{array}$ & $\begin{array}{l}\text { Proximal and mid } \\
\text { neuropodial } \\
\text { acicula; proximal } \\
\text { neuropodial } \\
\text { circumchaetal; } \\
\text { mid-parapodial } \\
\text { septal EC }\end{array}$ & $\begin{array}{l}\text { MNring; } \\
\text { fragments }\end{array}$ \\
\hline & & $\begin{array}{l}\text { dorsal } \\
\text { neuropodial } \\
\text { muscle to } \\
\text { notopodium }\end{array}$ & MUSac-neuDx & $\begin{array}{l}\text { sg1: 0l, } 0 \mathrm{r} \\
\text { sg2: } 2 \mathrm{l}, 2 \mathrm{r} \\
\text { sg3: } 2 \mathrm{l}, 2 \mathrm{r}\end{array}$ & $\begin{array}{l}\text { Proximal base of } \\
\text { neuropodial } \\
\text { acicula; mid-distal } \\
\text { notopodial acicula } \\
\text { and mid-dorsal } \\
\text { parapodial ECs } \\
\text { (2) }\end{array}$ & $\begin{array}{l}\text { MNcrab; } \\
\text { MNarm }\end{array}$ \\
\hline & & $\begin{array}{l}\text { dorsal } \\
\text { neuropodial } \\
\text { chaetal muscle }\end{array}$ & $\begin{array}{l}\text { MUSac- } \\
\text { neuDach }\end{array}$ & $\begin{array}{l}\text { sg1: } 31,3 r \\
\text { sg2: } 31,3 r \\
\text { sg3: } 31,3 r\end{array}$ & $\begin{array}{l}\text { Entire length of } \\
\text { neuropodial } \\
\text { acicula; mid- } \\
\text { parapodial ECs }\end{array}$ & $\begin{array}{l}\text { MNarm, } \\
\text { MNac }\end{array}$ \\
\hline & & $\begin{array}{l}\text { chaetal sac } \\
\text { retractor }\end{array}$ & MUSac-neure & $\begin{array}{l}\text { sg1: } 1 \mathrm{l}, 1 \mathrm{r} \\
\text { sg2: } 2 \mathrm{l}, 2 \mathrm{r} \\
\text { sg3: } 1 \mathrm{l}, 1 \mathrm{r}\end{array}$ & $\begin{array}{l}\text { Proximal base of } \\
\text { neuropodial } \\
\text { acicula; proximal } \\
\text { neuropodial } \\
\text { circumchaetal }\end{array}$ & sparse \\
\hline & Interacicular & $\begin{array}{l}\text { interacicular_mus } \\
\text { cle }\end{array}$ & MUSac-i & $\begin{array}{l}\text { sg1: } 1 \mathrm{l}, 1 \mathrm{r} \\
\text { sg2: } 1 \mathrm{l}, 1 \mathrm{r} \\
\text { sg3: } 1 \mathrm{l}, 1 \mathrm{r}\end{array}$ & $\begin{array}{l}\text { Proximal base of } \\
\text { neuropodial } \\
\text { acicula; proximal } \\
\text { base of } \\
\text { notopodial acicula }\end{array}$ & none \\
\hline $\begin{array}{l}\text { Anterior } \\
\text { oblique } \\
\text { muscle }\end{array}$ & $\begin{array}{l}\text { Anterior } \\
\text { ventral } \\
\text { oblique } \\
\text { muscles }\end{array}$ & $\begin{array}{l}\text { parapodial } \\
\text { retractor muscle }\end{array}$ & MUSobA-re & $\begin{array}{l}\text { sg1: } 61,5 r \\
\text { sg2: } 71,7 r \\
\text { sg3: } 71,7 r\end{array}$ & $\begin{array}{l}\text { Neuropodial EC } \\
\text { circumchaetal and } \\
\text { chaetal asc ECs; } \\
\text { midline cells }\end{array}$ & $\begin{array}{l}\text { MNspider- } \\
\text { ant; } \\
\text { MNantacic; } \\
\text { MNantelop } \\
\text { e; MNhose }\end{array}$ \\
\hline & & $\begin{array}{l}\text { ventral parapodial } \\
\text { muscle arc }\end{array}$ & MUSobA-arc & $\begin{array}{l}\text { sg1: } 21,2 r \\
\text { sg2: } 41,4 r \\
\text { sg3: } 31,3 r\end{array}$ & $\begin{array}{l}\text { Basal lamina next } \\
\text { to nerve chord; } \\
\text { neuropodial ECs } \\
\text { and circumchaetal } \\
\text { ECs }\end{array}$ & $\begin{array}{l}\text { MNspider- } \\
\text { ant; } \\
\text { MNantacic; } \\
\text { MNob- } \\
\text { contra }\end{array}$ \\
\hline & & $\begin{array}{l}\text { medial oblique to } \\
\text { mid-parapodium }\end{array}$ & MUSobA-mpp & $\begin{array}{l}\text { sg1: } 1 \mathrm{l}, 1 \mathrm{r} \\
\text { sg2: } 2 \mathrm{l}, 2 \mathrm{r} \\
\text { sg3: } 3 \mathrm{l}, 3 \mathrm{r}\end{array}$ & $\begin{array}{l}\text { Medial basal } \\
\text { lamina next to } \\
\text { medial nerve cord } \\
\text { and putative } \\
\text { radial glia; mid- } \\
\text { parapodial ECs }\end{array}$ & $\begin{array}{l}\text { MNob- } \\
\text { contra; } \\
\text { MNhose; } \\
\text { MNcrab }\end{array}$ \\
\hline & & $\begin{array}{l}\text { mediolateral } \\
\text { oblique to mid- } \\
\text { parapodium }\end{array}$ & MUSobA-mlpp & $\begin{array}{l}\text { sg1: 0l, Or } \\
\text { sg2: 2l, } 2 r \\
\text { sg3: 0l, Or }\end{array}$ & $\begin{array}{l}\text { Medial basal } \\
\text { lamina next to } \\
\text { mediolateral } \\
\text { nerve cord and } \\
\text { putative radial } \\
\text { glia; mid- } \\
\text { parapodial ECs }\end{array}$ & MNhose \\
\hline & & $\begin{array}{l}\text { lateral oblique to } \\
\text { mid-parapodium }\end{array}$ & MUSobA-Ipp & $\begin{array}{l}\text { sg1: } 1 \mathrm{l}, 1 \mathrm{r} \\
\text { sg2: } 2 \mathrm{l}, 2 \mathrm{r} \\
\text { sg3: } 2 \mathrm{l}, 2 \mathrm{r}\end{array}$ & $\begin{array}{l}\text { Lateral basal } \\
\text { lamina next to the } \\
\text { nerve cord and } \\
\text { putative radial } \\
\text { glia; mid- } \\
\text { parapodial ECs }\end{array}$ & $\begin{array}{l}\text { MNob- } \\
\text { contra; } \\
\text { MNhose; } \\
\text { MNring; } \\
\text { MN_obliqu } \\
\text { e; } \\
\text { MNspider- } \\
\text { ant }\end{array}$ \\
\hline
\end{tabular}


bioRxiv preprint doi: https://doi.org/10.1101/2021.06.09.447732; this version posted June 10, 2021. The copyright holder for this preprint (which was not certified by peer review) is the author/funder, who has granted bioRxiv a license to display the preprint in perpetuity. It is made available under aCC-BY-NC 4.0 International license.

\begin{tabular}{|c|c|c|c|c|c|c|}
\hline & & $\begin{array}{l}\text { oblique to start of } \\
\text { transverse }\end{array}$ & MUSobA-trans & $\begin{array}{l}\text { sg1: } 1 \mathrm{l}, 1 \mathrm{r} \\
\text { sg2: } 2 \mathrm{l}, 2 \mathrm{r} \\
\text { sg3: } 2 \mathrm{l}, 2 \mathrm{r}\end{array}$ & $\begin{array}{l}\text { Basal lamina next } \\
\text { to the axochord; } \\
\text { ventrolateral ECs }\end{array}$ & MNhose \\
\hline \multirow[t]{9}{*}{$\begin{array}{l}\text { Posterior } \\
\text { oblique } \\
\text { muscle }\end{array}$} & \multirow[t]{4}{*}{$\begin{array}{l}\text { Posterior } \\
\text { dorsal } \\
\text { oblique } \\
\text { muscle }\end{array}$} & $\begin{array}{l}\text { notopodial dorsal } \\
\text { oblique muscle }\end{array}$ & MUSobP-notD & $\begin{array}{l}\text { sg1: } 41,4 r \\
\text { sg2: } 51,5 r \\
\text { sg3: } 51,5 r\end{array}$ & $\begin{array}{l}\text { Dorsal } \\
\text { longitudinal } \\
\text { muscles and ECs } \\
\text { near them; ECs of } \\
\text { the notopodium }\end{array}$ & MNpostacic \\
\hline & & $\begin{array}{l}\text { neuropodial } \\
\text { dorsal oblique } \\
\text { long }\end{array}$ & $\begin{array}{l}\text { MUSobP- } \\
\text { neuDlong }\end{array}$ & $\begin{array}{l}\text { sg1: } 1 \mathrm{l}, 1 \mathrm{r} \\
\text { sg2: } 2 \mathrm{l}, 2 \mathrm{r} \\
\text { sg3: } 2 \mathrm{l}, 1 \mathrm{r}\end{array}$ & $\begin{array}{l}\text { MUSlong_d; distal } \\
\text { neuropodial } \\
\text { circumacicular, } \\
\text { neuropodial ECs } \\
\text { and mid- } \\
\text { parapodial ECs }\end{array}$ & $\begin{array}{l}\text { MNspider- } \\
\text { post; } \\
\text { MNpostacic }\end{array}$ \\
\hline & & $\begin{array}{l}\text { neuropodial } \\
\text { dorsal oblique } \\
\text { proximal }\end{array}$ & $\begin{array}{l}\text { MUSobP- } \\
\text { neuDprox }\end{array}$ & $\begin{array}{l}\text { sg1: } 31,3 r \\
\text { sg2: } 31,3 r \\
\text { sg3: } 31,3 r\end{array}$ & $\begin{array}{l}\text { MUSlong_d; } \\
\text { dorsal paratroch } \\
\text { and ECs around it }\end{array}$ & $\begin{array}{l}\text { MNspider- } \\
\text { post }\end{array}$ \\
\hline & & $\begin{array}{l}\text { neuropodial } \\
\text { dorsal oblique } \\
\text { distal }\end{array}$ & $\begin{array}{l}\text { MUSobP- } \\
\text { neuDdist }\end{array}$ & $\begin{array}{l}\text { sg1: } 31,3 r \\
\text { sg2: } 31,3 r \\
\text { sg3: } 31,3 r\end{array}$ & $\begin{array}{l}\text { ECs near dorsal } \\
\text { paratroch; distal } \\
\text { neuropodial } \\
\text { circumacicular, } \\
\text { neuropodial ECs } \\
\text { and mid- } \\
\text { parapodial ECs }\end{array}$ & MNbow \\
\hline & \multirow[t]{4}{*}{$\begin{array}{l}\text { Posterior } \\
\text { ventral } \\
\text { oblique } \\
\text { muscle }\end{array}$} & $\begin{array}{l}\text { posterior ventral } \\
\text { neuropodial } \\
\text { muscle }\end{array}$ & MUSobP-neuV & $\begin{array}{l}\text { sg1: } 5 \mathrm{l}, 5 \mathrm{r} \\
\text { sg2: } 71,7 \mathrm{r} \\
\text { sg3: } 71,7 \mathrm{r}\end{array}$ & $\begin{array}{l}\text { Basal lamina next } \\
\text { to VNC; ECs from } \\
\text { the distal part of } \\
\text { neuropodial } \\
\text { acicula to the } \\
\text { ventral paratroch } \\
\text { area }\end{array}$ & $\begin{array}{l}\text { MNspider- } \\
\text { post; } \\
\text { MNhose; } \\
\text { MNob-ipsi; } \\
\text { MN_obliqu } \\
\text { e; MNring; } \\
\text { MNob; } \\
\text { MNarm; } \\
\text { many } \\
\text { fragments }\end{array}$ \\
\hline & & $\begin{array}{l}\text { posterior ventral } \\
\text { notopodial muscle }\end{array}$ & MUSobP-notV & $\begin{array}{l}\text { sg1: } 31,3 r \\
\text { sg2: } 31,3 r \\
\text { sg3: } 31,3 r\end{array}$ & $\begin{array}{l}\text { Basal lamina next } \\
\text { to VNC; septal } \\
\text { ECs; EC and } \\
\text { circumchaetal } \\
\text { near distal part of } \\
\text { notopodial acicula }\end{array}$ & $\begin{array}{l}\text { MNhose; } \\
\text { MNspider- } \\
\text { post; } \\
\text { MNob-ipsi; } \\
\text { MN_obliqu } \\
\text { e; } \\
\text { MNladder; } \\
\text { MNob; } \\
\text { MNarm; } \\
\text { MNchae; } \\
\text { fragments }\end{array}$ \\
\hline & & $\begin{array}{l}\text { oblique to distal } \\
\text { interacicular }\end{array}$ & MUSobP-M & $\begin{array}{l}\text { sg1: } 01,0 r \\
\text { sg2: } 11,1 r \\
\text { sg3: } 11,1 r\end{array}$ & $\begin{array}{l}\text { Each other and } \\
\text { basal lamina of } \\
\text { the VNC; distal } \\
\text { interacicular } \\
\text { muscle }\end{array}$ & none \\
\hline & & $\begin{array}{l}\text { oblique to body } \\
\text { wall near distal } \\
\text { interacicular and } \\
\text { neuropodial } Y\end{array}$ & MUSobP-noty & $\begin{array}{l}\text { sg1: } 1 \mathrm{l}, 1 \mathrm{r} \\
\text { sg2: } 1 \mathrm{l}, 1 \mathrm{r} \\
\text { sg3: } 1 \mathrm{l}, 1 \mathrm{r}\end{array}$ & $\begin{array}{l}\text { Basal lamina next } \\
\text { to the axochord; } \\
\text { septal ECs }\end{array}$ & $\begin{array}{l}\text { MNhose; } \\
\text { MNob-ipsi; } \\
\text { MNspider- } \\
\text { post; } \\
\text { fragments }\end{array}$ \\
\hline & & $\begin{array}{l}\text { distal interacicular } \\
\text { muscle }\end{array}$ & MUSobP-i & $\begin{array}{l}\text { sg1: } 11,1 r \\
\text { sg2: } 11,1 r \\
\text { sg3: } 11,1 r\end{array}$ & $\begin{array}{l}\text { Neuropodial EC, } \\
\text { circumchaetal EC, } \\
\text { circumacicular } \\
\text { EC; notopodial } \\
\text { EC, circumchaetal } \\
\text { EC; MUSob- } \\
\text { postM }\end{array}$ & sparse \\
\hline
\end{tabular}


bioRxiv preprint doi: https://doi.org/10.1101/2021.06.09.447732; this version posted June 10, 2021. The copyright holder for this preprint (which was not certified by peer review) is the author/funder, who has granted bioRxiv a license to display the preprint in perpetuity. It is made available under aCC-BY-NC 4.0 International license.

\begin{tabular}{|c|c|c|c|c|c|c|}
\hline \multirow{9}{*}{$\begin{array}{l}\text { Chaetal } \\
\text { sac } \\
\text { muscle }\end{array}$} & \multirow[t]{6}{*}{ Notopodial } & $\begin{array}{l}\text { notochaetal next } \\
\text { to dorsal oblique }\end{array}$ & $\begin{array}{l}\text { MUSchae- } \\
\text { notDob }\end{array}$ & $\begin{array}{l}\text { sg1: } 31,3 r \\
\text { sg2: } 31,3 r \\
\text { sg3: } 31,3 r\end{array}$ & $\begin{array}{l}\text { Dorsolateral ECs; } \\
\text { notopodial } \\
\text { circumchaetal }\end{array}$ & $\begin{array}{l}\text { MNpostacic } \\
\text {; fragments }\end{array}$ \\
\hline & & $\begin{array}{l}\text { dorsal notopodial } \\
\text { chaetal sac } \\
\text { muscle }\end{array}$ & MUSchae-notD & $\begin{array}{l}\text { sg1: } 11,1 r \\
\text { sg2: } 11,1 r \\
\text { sg3: } 11,1 r\end{array}$ & $\begin{array}{l}\text { Proximal } \\
\text { notopodial } \\
\text { acicula; } \\
\text { notopodial } \\
\text { circumchaetal } \\
\text { (semicircle } \\
\text { around dorsal } \\
\text { side of notopodial } \\
\text { chaetal sac) }\end{array}$ & sparse \\
\hline & & $\begin{array}{l}\text { next to dorsal } \\
\text { notopodial chaetal } \\
\text { sac muscle }\end{array}$ & $\begin{array}{l}\text { MUSchae- } \\
\text { notDn }\end{array}$ & $\begin{array}{l}\text { sg1: } 11,1 \mathrm{r} \\
\text { sg2: } 11,1 \mathrm{r} \\
\text { sg3: } 11,1 \mathrm{r}\end{array}$ & $\begin{array}{l}\text { Dorsolateral ECs; } \\
\text { ECs of the } \\
\text { notopodial chaetal } \\
\text { sac and } \\
\text { notopodial } \\
\text { circumchaetal } \\
\text { ECs; notopodial } \\
\text { circumacicular } \\
\text { cells }\end{array}$ & MNpostacic \\
\hline & & $\begin{array}{l}\text { anterior } \\
\text { notopodial chaetal } \\
\text { sac muscle }\end{array}$ & MUSchae-notA & $\begin{array}{l}\text { sg1: } 1 l, 1 r \\
\text { sg2: } 11,1 r \\
\text { sg3: } 11,1 r\end{array}$ & $\begin{array}{l}\text { Mid parapodial } \\
\text { chaetal sac ECs } \\
\text { and MUSobA- } \\
\text { che; notopodial } \\
\text { ECs, } \\
\text { circumchaetal } \\
\text { ECs and } \\
\text { circumacicular }\end{array}$ & $\begin{array}{l}\text { MNspider- } \\
\text { ant; } \\
\text { MNantacic }\end{array}$ \\
\hline & & $\begin{array}{l}\text { notopodial chaetal } \\
\text { muscle under } \\
\text { acicula }\end{array}$ & $\begin{array}{l}\text { MUSchae- } \\
\text { notAac }\end{array}$ & $\begin{array}{l}\text { sg1: } 4 I, 4 r \\
\text { sg2: } 4 I, 4 r \\
\text { sg3: } 4 I, 4 r\end{array}$ & $\begin{array}{l}\text { Distal } \\
\text { circumacicular; all } \\
\text { types of chaetal } \\
\text { sac cells }\end{array}$ & $\begin{array}{l}\text { MNcrab; } \\
\text { MNbiramou } \\
\text { s; MNwave; } \\
\text { MNantacic; } \\
\text { MNacic; } \\
\text { MNspider- } \\
\text { ant; } \\
\text { MNbow; } \\
\text { fragments }\end{array}$ \\
\hline & & $\begin{array}{l}\text { notopodial } \\
\text { retractor muscle }\end{array}$ & $\begin{array}{l}\text { MUSchae- } \\
\text { notAre }\end{array}$ & $\begin{array}{l}\text { sg1: 0l, } 0 \mathrm{r} \\
\text { sg2: } 11,1 \mathrm{r} \\
\text { sg3: } 11,1 \mathrm{r}\end{array}$ & $\begin{array}{l}\text { Mid-parapodial } \\
\text { ECs; distal } \\
\text { notopodial } \\
\text { circumacicular } \\
\text { and EC } \\
\text { circumchaetal }\end{array}$ & sparse \\
\hline & \multirow[t]{3}{*}{ Neuropodial } & $\begin{array}{l}\text { neurochaetal next } \\
\text { to ventral oblique }\end{array}$ & $\begin{array}{l}\text { MUSchae- } \\
\text { neuVob }\end{array}$ & $\begin{array}{l}\text { sg1: } 2 \mathrm{l}, 2 \mathrm{r} \\
\text { sg2: } 31,3 r \\
\text { sg3: } 2 l, 2 r\end{array}$ & $\begin{array}{l}\text { Proximal } \\
\text { neuropodial } \\
\text { hemichaetal; } \\
\text { ventrolateral ECs }\end{array}$ & MNchae \\
\hline & & $\begin{array}{l}\text { neuropodial } \\
\text { chaetal muscle } \\
\text { under acicula }\end{array}$ & $\begin{array}{l}\text { MUSchae- } \\
\text { neuDac }\end{array}$ & $\begin{array}{l}\text { sg1: } 41,4 r \\
\text { sg2: } 5 l, 5 r \\
\text { sg3: } 51,5 r\end{array}$ & $\begin{array}{l}\text { Mid and distal } \\
\text { neuropodial } \\
\text { circumacicluar } \\
\text { cells; proximal } \\
\text { and distal } \\
\text { circumchaetal } \\
\text { cells and chaetal } \\
\text { sac ECs }\end{array}$ & $\begin{array}{l}\text { MNbiramou } \\
\text { s; MNchae; } \\
\text { MNspider- } \\
\text { ant; } \\
\text { fragments }\end{array}$ \\
\hline & & $\begin{array}{l}\text { anterior ventral } \\
\text { neurochaetal } \\
\text { muscle ob }\end{array}$ & $\begin{array}{l}\text { MUSchae- } \\
\text { neuAVo }\end{array}$ & $\begin{array}{l}\text { sg1: } 21,2 r \\
\text { sg2: } 31,3 r \\
\text { sg3: } 31,3 r\end{array}$ & $\begin{array}{l}\text { Neuropodial mid } \\
\text { circumacicular } \\
\text { and proximal } \\
\text { circumchaetal; } \\
\text { distal } \\
\text { circumchaetal and } \\
\text { neuropodial ECs }\end{array}$ & $\begin{array}{l}\text { MNarm; } \\
\text { MNchae }\end{array}$ \\
\hline
\end{tabular}


bioRxiv preprint doi: https://doi.org/10.1101/2021.06.09.447732; this version posted June 10,2021 . The copyright holder for this preprint (which was not certified by peer review) is the author/funder, who has granted bioRxiv a license to display the preprint in perpetuity. It is made available under aCC-BY-NC 4.0 International license.

\begin{tabular}{|c|c|c|c|c|c|c|}
\hline & & $\begin{array}{l}\text { anterior ventral } \\
\text { neurochaetal } \\
\text { muscle trans }\end{array}$ & $\begin{array}{l}\text { MUSchae- } \\
\text { neuAVt }\end{array}$ & $\begin{array}{l}\text { sg1: } 11,1 \mathrm{r} \\
\text { sg2: } 11,1 \mathrm{r} \\
\text { sg3: } 11,1 \mathrm{r}\end{array}$ & $\begin{array}{l}\text { Distal neuropodial } \\
\text { circumacicular 4; } \\
\text { ventrolateral ECs } \\
\text { next to VLM }\end{array}$ & $\begin{array}{l}\text { MNacicX; } \\
\text { MNspider- } \\
\text { post }\end{array}$ \\
\hline & & $\begin{array}{l}\text { chaetal sac under } \\
\text { parapodial } \\
\text { retractor }\end{array}$ & MUSchae-Are & $\begin{array}{l}\text { sg1: } 11,1 \mathrm{r} \\
\text { sg2: } 11,1 \mathrm{r} \\
\text { sg3: } 11,1 \mathrm{r}\end{array}$ & $\begin{array}{l}\text { Mid and distal } \\
\text { neuropodial } \\
\text { circumchaetal } \\
\text { cells }\end{array}$ & $\begin{array}{l}\text { MNbiramou } \\
\text { s; } \\
\text { MNspider- } \\
\text { ant }\end{array}$ \\
\hline $\begin{array}{l}\text { Transvers } \\
\text { e muscle }\end{array}$ & & transverse muscle & MUStrans & $\begin{array}{l}\text { sg0: } 41,5 r \\
\text { sg1: } 51,5 r \\
\text { sg2: } 91,9 r \\
\text { sg3: } 81,9 r \\
\text { pyg: } 41,4 r\end{array}$ & $\begin{array}{l}\text { Lateral ECs; } \\
\text { metatroch; } \\
\text { akrotroch }\end{array}$ & $\begin{array}{l}\text { MNring; } \\
\text { MNhose; } \\
\text { MNsmile; } \\
\text { MNob- } \\
\text { contra; } \\
\text { MNladder }\end{array}$ \\
\hline \multirow[t]{3}{*}{$\begin{array}{l}\text { Longitudi } \\
\text { nal } \\
\text { muscle }\end{array}$} & Dorsolateral & $\begin{array}{l}\text { dorsolateral } \\
\text { muscle }\end{array}$ & MUSlongD & $\begin{array}{l}\text { sg0: 11l, } \\
\text { 15r } \\
\text { sg1: 13I, } \\
\text { 15r } \\
\text { sg2: 10I, } \\
\text { 10r } \\
\text { sg3: } 71,7 r\end{array}$ & $\begin{array}{l}\text { Epithelial cells; } \\
\text { MUSobP-neuD, } \\
\text { MUSobP- } \\
\text { notDprox, } \\
\text { MUSobP- } \\
\text { notDlong; } \\
\text { paratroch; nuchal } \\
\text { organ }\end{array}$ & $\begin{array}{l}\text { MN2; } \\
\text { MNring; } \\
\text { MNcrab }\end{array}$ \\
\hline & $\begin{array}{l}\text { Ventrolatera } \\
\text { I }\end{array}$ & $\begin{array}{l}\text { ventrolateral } \\
\text { muscle }\end{array}$ & MUSlongV & $\begin{array}{l}\text { head: } 9 \mathrm{l}, \\
8 \mathrm{r}, 1 \mathrm{~m} \\
\text { sg0: } 7 \mathrm{l}, 4 \mathrm{r} \\
\text { sg1: } 8 \mathrm{l}, \\
\text { 12r } \\
\text { sg2: } 11 \mathrm{l}, \\
8 \mathrm{r} \\
\text { sg3: } 7 \mathrm{l}, 7 \mathrm{r} \\
\text { pyg: } 11,1 \mathrm{r}\end{array}$ & $\begin{array}{l}\text { Basal lamina at } \\
\text { VNC; ventral ECs }\end{array}$ & $\begin{array}{l}\text { MN1; } \\
\text { MNring; } \\
\text { MNcrab; } \\
\text { MNsmile }\end{array}$ \\
\hline & Axochord & axochord & MUSax & $\begin{array}{l}\text { sg1: } 41,4 r \\
\text { sg2: } 11,1 r \\
\text { sg3: } 11,1 r\end{array}$ & $\begin{array}{l}\text { Basal lamina next } \\
\text { to VNC; radial } \\
\text { glia; ECs }\end{array}$ & $\begin{array}{l}\text { MNax; } \\
\text { MNsmile }\end{array}$ \\
\hline \multirow[t]{3}{*}{$\begin{array}{l}\text { Digestive } \\
\text { systems } \\
\text { muscle }\end{array}$} & $\begin{array}{l}\text { Circular } \\
\text { pygidial } \\
\text { muscle }\end{array}$ & & MUSring_pyg & pyg1 & $\begin{array}{l}\text { Self; dorsal } \\
\text { pygidial ECs; } \\
\text { ventral pygidial } \\
\text { ECs }\end{array}$ & none \\
\hline & $\begin{array}{l}\text { Pharyngeal } \\
\text { muscle }\end{array}$ & & MUSph & $28 \mathrm{I}, 30 \mathrm{r}$ & Basal lamina & none \\
\hline & $\begin{array}{l}\text { Lower lip } \\
\text { muscle }\end{array}$ & & MUSII & $5 \mathrm{I}, 5 \mathrm{r}$ & $\begin{array}{l}\text { Metatroch and } \\
\text { ECs next to } \\
\text { metatroch }\end{array}$ & MNsmile \\
\hline \multirow{5}{*}{$\begin{array}{l}\text { Head } \\
\text { muscle }\end{array}$} & \multirow{4}{*}{$\begin{array}{l}\text { Head } \\
\text { appendage }\end{array}$} & antenna muscle & MUSant & $4 \mathrm{l}, 4 \mathrm{r}$ & ECs & sparse \\
\hline & & lyrate muscle & MUSly & $3 \mathrm{l}, 3 \mathrm{r}$ & Basal lamina & none \\
\hline & & palp muscle & MUSpl & $2 \mathrm{l}, 2 \mathrm{r}$ & $\begin{array}{l}\text { ECs and cover } \\
\text { cells }\end{array}$ & none \\
\hline & & cirrus muscle & MUSci & $2 \mathrm{l}, 2 \mathrm{r}$ & $\begin{array}{l}\text { ECs and basal } \\
\text { lamina }\end{array}$ & none \\
\hline & Other head & cheek muscle & MUSch & $31,3 r$ & Basal lamina & MNsmile \\
\hline
\end{tabular}


bioRxiv preprint doi: https://doi.org/10.1101/2021.06.09.447732; this version posted June 10, 2021. The copyright holder for this preprint (which was not certified by peer review) is the author/funder, who has granted bioRxiv a license to display the preprint in perpetuity. It is made available under aCC-BY-NC 4.0 International license.

\begin{tabular}{|l|l|l|l|l|l|l|}
\hline & Plexus muscle & MUSpx & 1 & $\begin{array}{l}\text { ECs and putative } \\
\text { glia }\end{array}$ & $\begin{array}{l}\text { SNs with } \\
\text { very weak } \\
\text { connection } \\
\text { s }\end{array}$ \\
\cline { 3 - 6 } & $\begin{array}{l}\text { ventral transverse } \\
\text { muscle of } \\
\text { prostomium }\end{array}$ & MUSpr-Vt & 1 & $\begin{array}{l}\text { Dorsolateral head } \\
\text { ECs }\end{array}$ & sparse \\
\cline { 2 - 6 } & \begin{tabular}{l} 
triangle muscle \\
\cline { 2 - 6 }
\end{tabular} & MUStri & $11 ; 1 \mathrm{r}$ & Basal lamina & none \\
\cline { 2 - 6 } & $\begin{array}{l}\text { smooth head } \\
\text { muscles }\end{array}$ & MUSmed-head & $11,1 \mathrm{r}$ & Head ECs & none \\
\hline
\end{tabular}

Table 1. Hierarchical classification and nomenclature of all muscle cells in the 3-dayold Platynereis larva.

\section{Figure supplements}
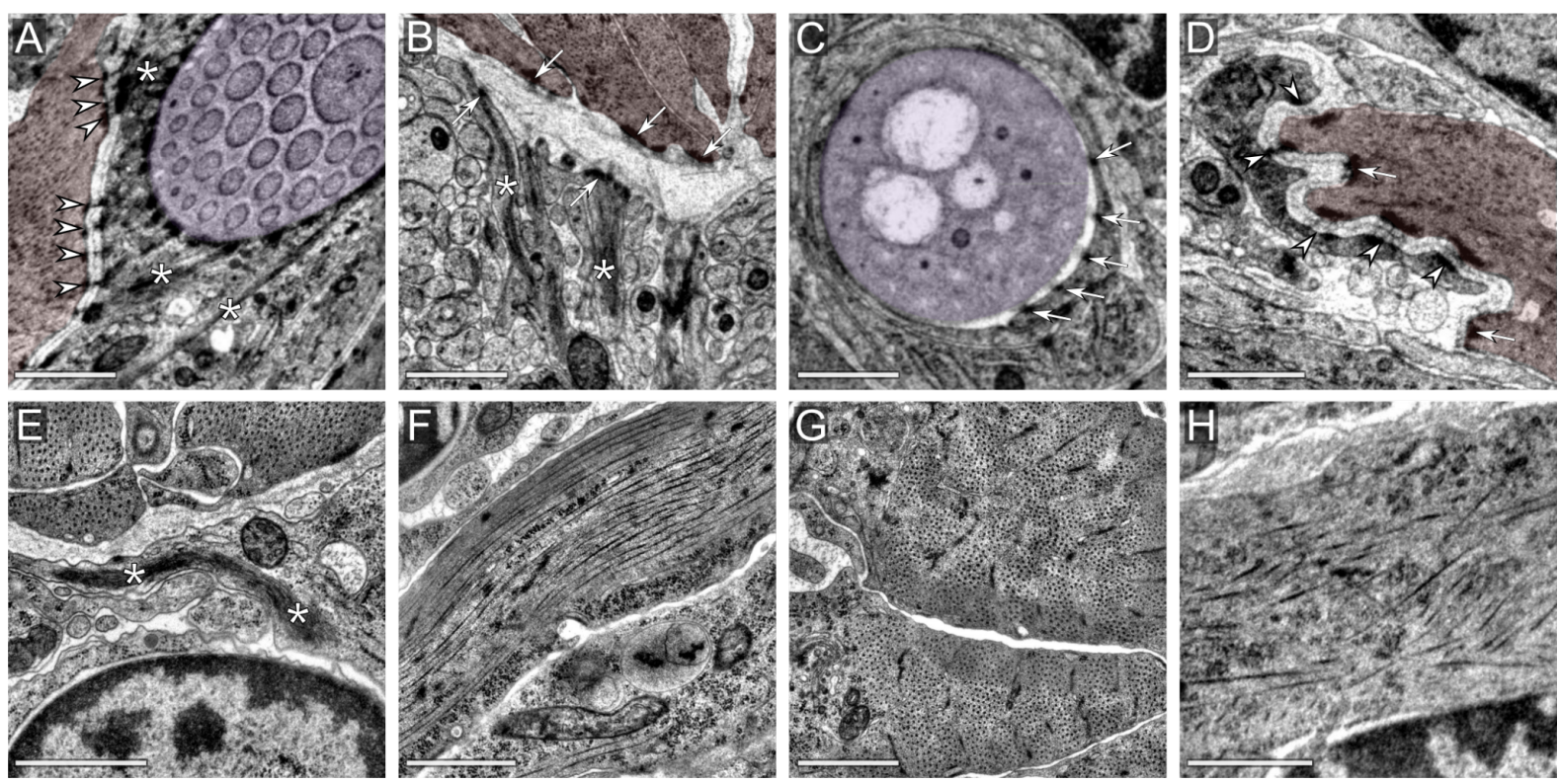

Figure 1 - figure supplement 1. Desmosome and muscle ultrastructure.

(A) Desmosomes between aciculoblast and muscle cells. (B) Hemidesmosomes of muscles and midline cells. Intermediate filaments connected to hemidesmosomes are visible in the midline cells.

(C) Hemidesmosomes from a circumacicular cell to an acicula. (D) Desmosomes between muscle and epithelial cells. (E) Intermediate filaments in a midline cell. (F) Striated muscle, longitudinal crosssection. (G) Striated muscle, transverse section. $(H)$ Smooth head muscle. Scale bars: $A, B, E, F, G=$ $1 \mu \mathrm{m} ; \mathrm{C}, \mathrm{D}, \mathrm{H}=0.75 \mu \mathrm{m}$. Arrows mark hemidesmosomes, arrowheads desmosomes and asterisks intermediate filaments. In the top row, muscles are coloured in red and acicula in purple. 


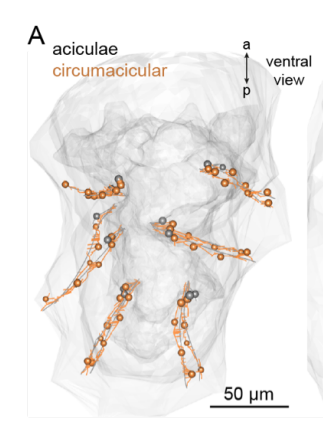

$\mathrm{D}$

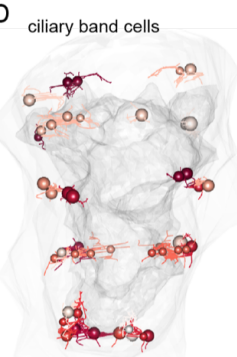

B

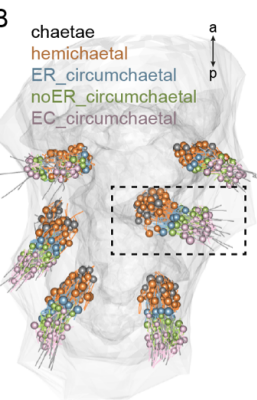

$\mathrm{F}$

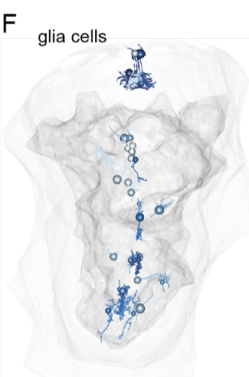

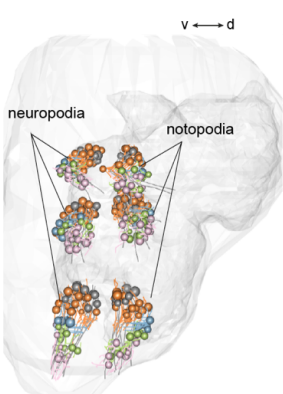

G

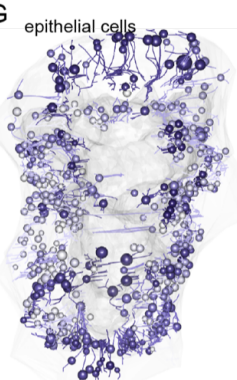

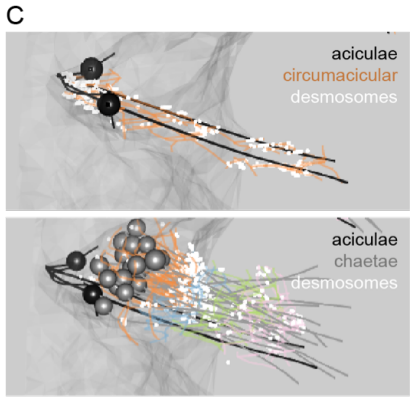

$\mathrm{H}$ basal lamina fragments
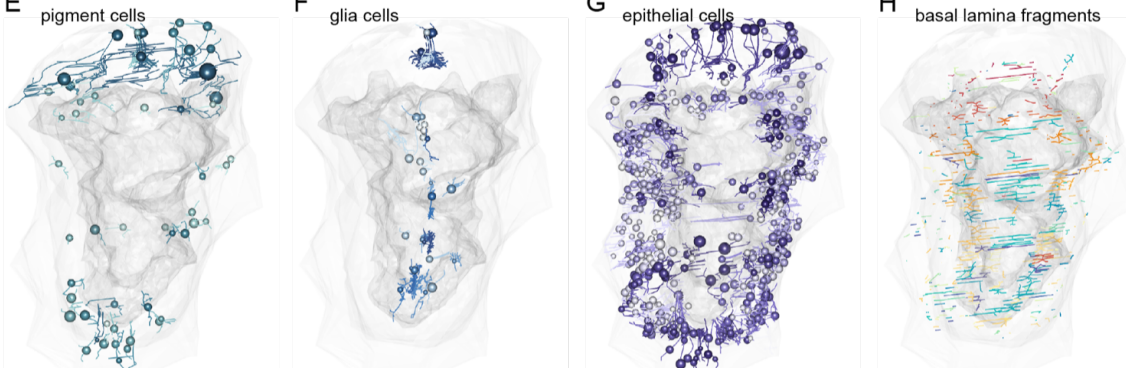

Figure 1 - figure supplement 2. Non-muscle components of the desmosomal connectome. Aciculae and circumacicular cells. (B) Chaetae and the four types of chaetal sac follicular cells. The region in the inset is shown in $\mathrm{C}$. (C) Close-up of the left parapodium in the second segment with aciculae, chaetae, desmosomes (white) and follicular cells (somas not shown). (D) Ciliary band cells that have desmosomal contacts with muscles. (E) Pigment cells that have desmosomal contacts with muscles. (F) Glial cells that have desmosomal contacts with muscles. (F) Glial cells that have desmosomal contacts with muscles. $(G)$ Epithelial cells that have desmosomal contacts with muscles. $(\mathrm{H})$ Basal lamina fragments that have desmosomal contacts either with muscles or other cells. 
A
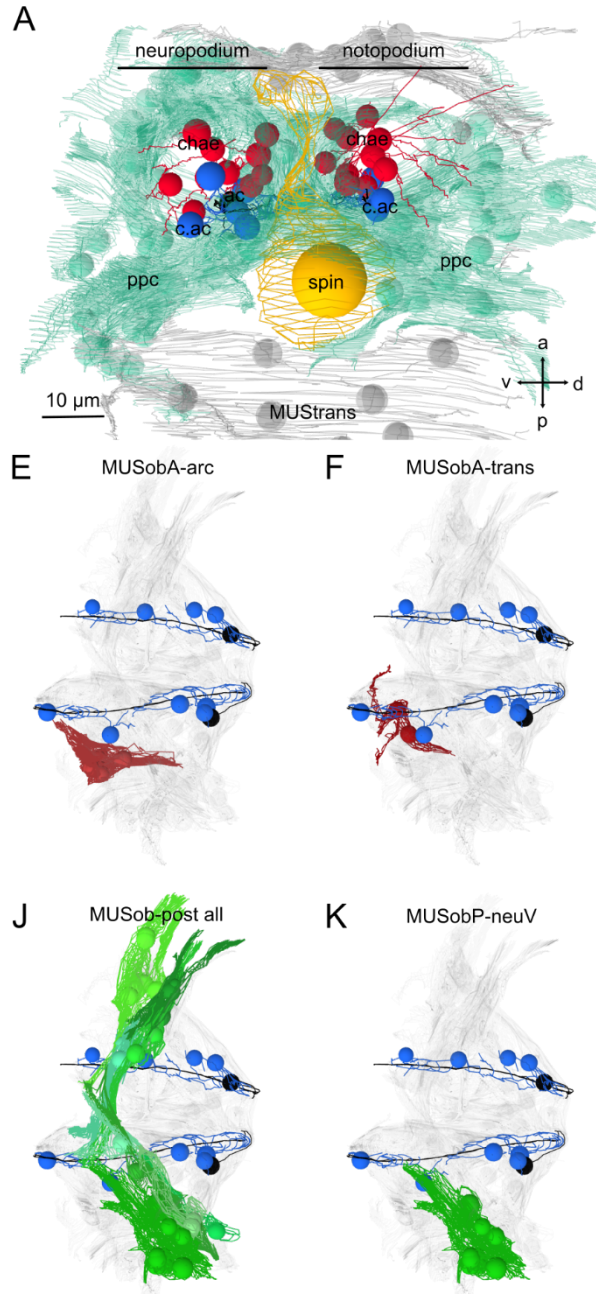

O MUSobP-M
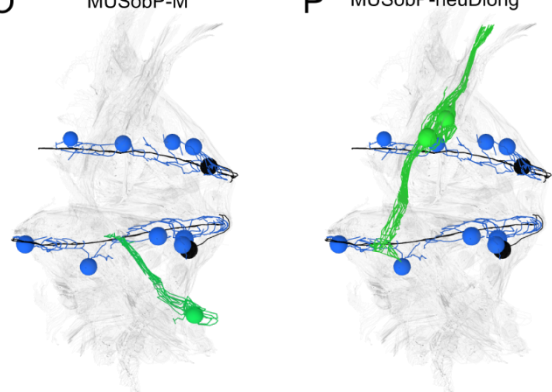

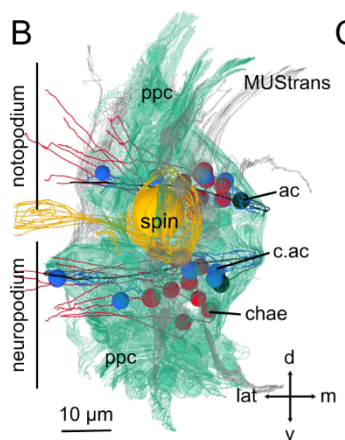

C

MUSobA all

G MUSobA-mpp
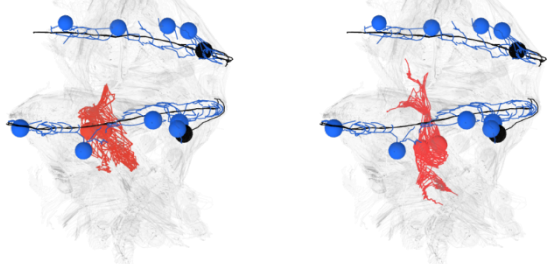

M

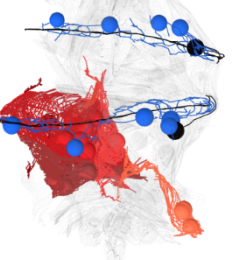

H MUSobA-Ipp

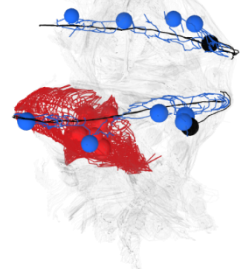

I MUSobA-mIpp

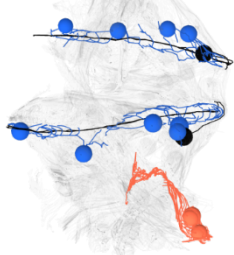

N MUSobP-noty
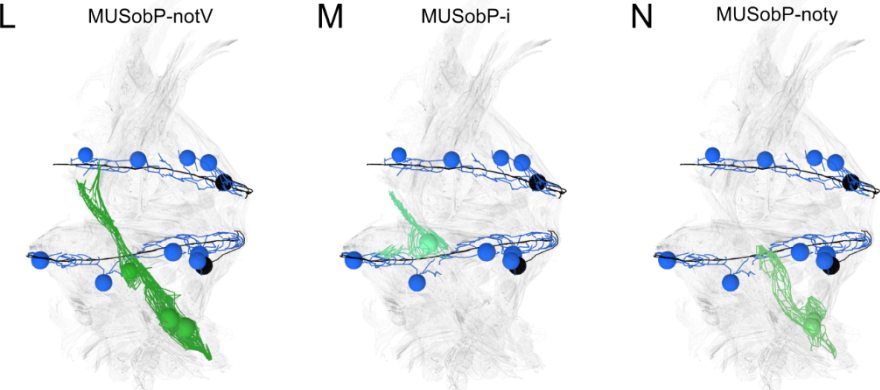

Q MUSobP-neuDdist

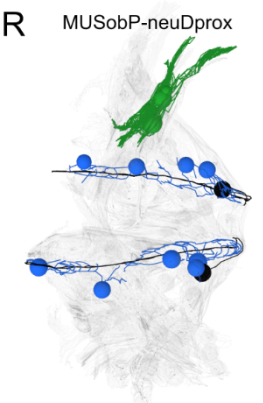

D MUSobA-re

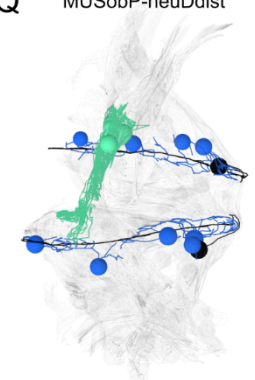

S MUSobP-hotD

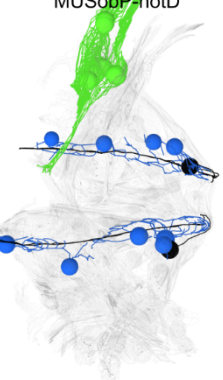

Figure 6 - figure supplement 1 . Oblique muscles.

(A) Lateral and (B) posterior views of a parapodium (second segment, left side) with a neuropodial and notopodial lobe and a spinning gland. (C) All anterior oblique muscles. Outline of (D) MUSobA-re, (E) MUSobA-arc, (F) MUSobA-trans, (G) MUSobA-mpp, (H) MUSobA-mpp and (I) MUSobA-mmpp muscles. (J) All posterior oblique muscles. Outline of (K) MUSobP-neuV, (L) MUSobP-notV, (M) MUSobP-i, (N) MUSobP-noty, (O) MUSob-postM, (P) MUSobP-neuDlong, (Q) MUSobP-neuDdist, (R) MUSobP-neuDprox and (S) MUSobP-notD muscles. The aciculae (black) and circumacicular cells (blue) are shown for reference. Directions: $a$ - anterior, $p$ - posterior, $v$ - ventral, $d$ - dorsal, $m$ medial, lat - lateral. ac - acicula, c.ac - circumacicular, chase - chaetae, ppc - parapodial complex, spin - spinning gland. 
bioRxiv preprint doi: https://doi.org/10.1101/2021.06.09.447732; this version posted June 10, 2021. The copyright holder for this preprint (which was not certified by peer review) is the author/funder, who has granted bioRxiv a license to display the preprint in perpetuity. It is made available under aCC-BY-NC 4.0 International license.

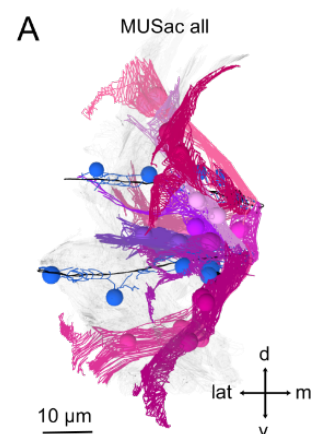

F MUSac-neuDach

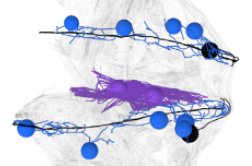

K

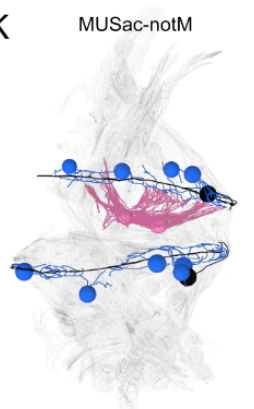

$\mathrm{P}$

MUSchae-Are

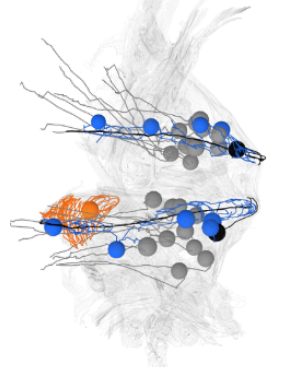

U MUSchae-notA

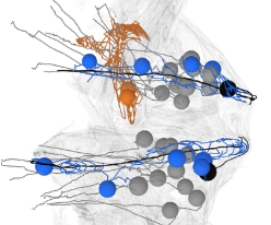

B MUSac-neuAV

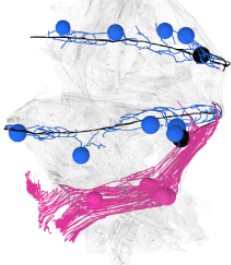

G

MUSac-neuDx

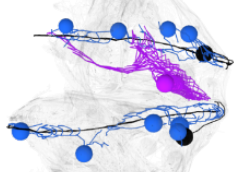

L

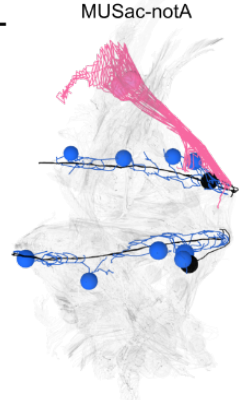

Q MUSchae-neuAVt
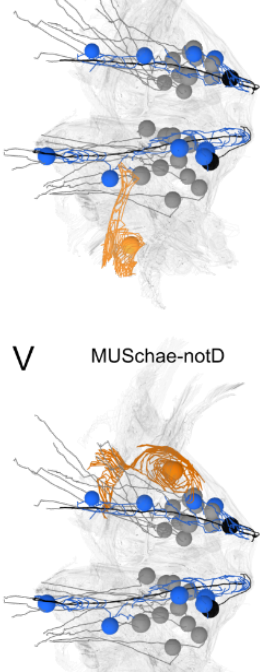

C MUSac-neuPV

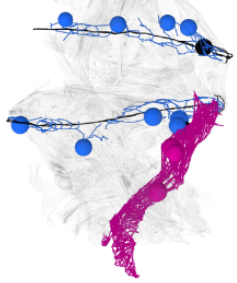

H MUSac-neure
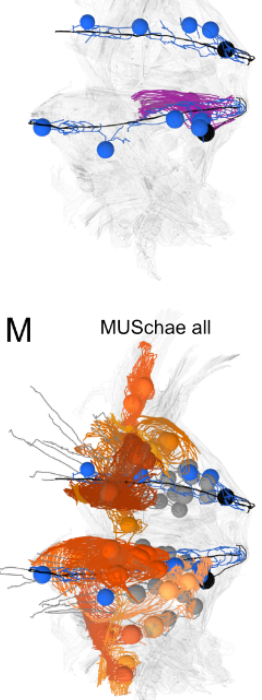

R MUSchae-neuVob

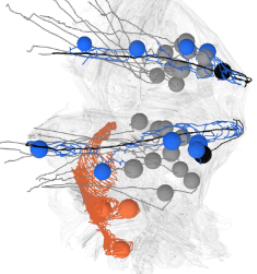

W MUSchae-notDob

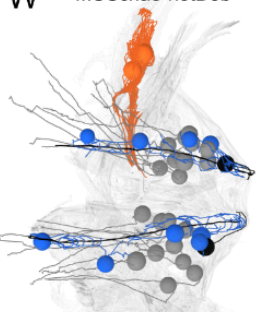

D MUSac-neuDy

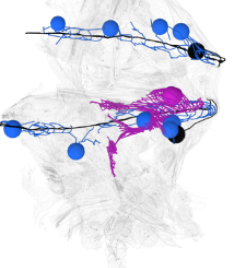

I

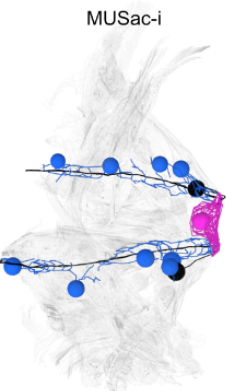

N MUSchae-neuDac

O MUSchae-neuAVo

J MUSac-notP

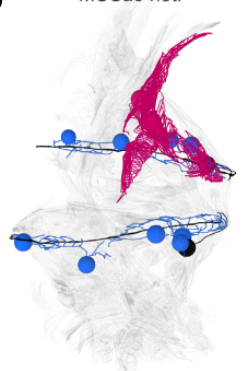

S MUSchae-notAre

T MUSchae-notDn
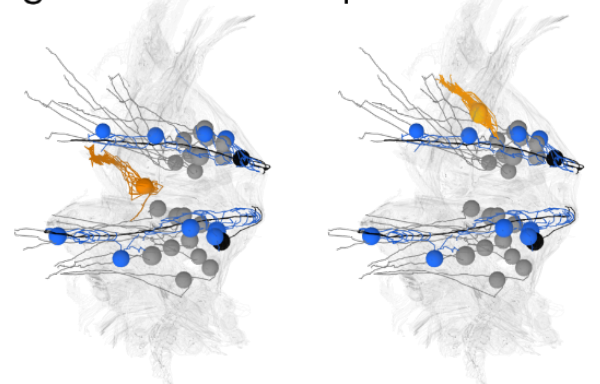

X MUSchae-notAac
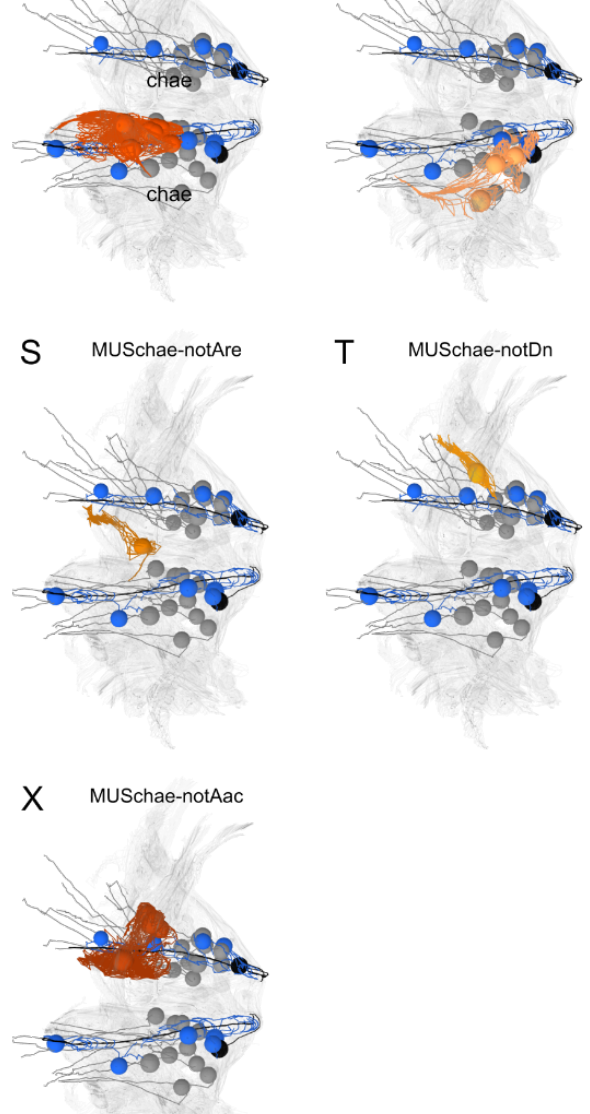

E MUSac-neuPD

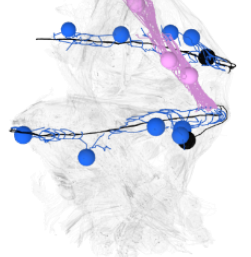

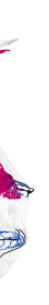
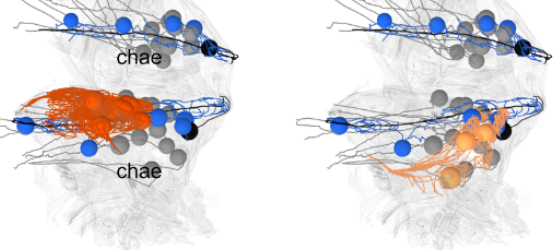

Figure 6 - figure supplement 2. Acicular and chaetal muscles.

(A) Posterior view of a parapodium (second segment, left side) with all acicular muscles shown. (B) Outline of MUSac-neuAV (C) MUSac-neuPV, (D) MUSac-neuDy, (E) MUSac-neuPD, (F) MUSacneuDach, (G) MUSac-neuDx, (H) MUSac-neure, (I) MUSac-i, (J) MUSac-notP, (K) MUSac-notM and 
bioRxiv preprint doi: https://doi.org/10.1101/2021.06.09.447732; this version posted June 10, 2021. The copyright holder for this preprint (which was not certified by peer review) is the author/funder, who has granted bioRxiv a license to display the preprint in perpetuity. It is made available under aCC-BY-NC 4.0 International license.

(L) MUSac-notA muscles. (M) all chaetal muscles. Outline of (N) MUSchae-neuDac, (O) MUSchaeneuAVo, (P) MUSchae-neuAre, (Q) MUSchae-neuAVt, (R) MUSchae-neuVob, (S) MUSchae-notAre (T) MUSchae-notDn, (U) MUSchae-notA, (V) MUSchae-notD, (W) MUSchae-notDob and (X) MUSchae-notAc muscles.
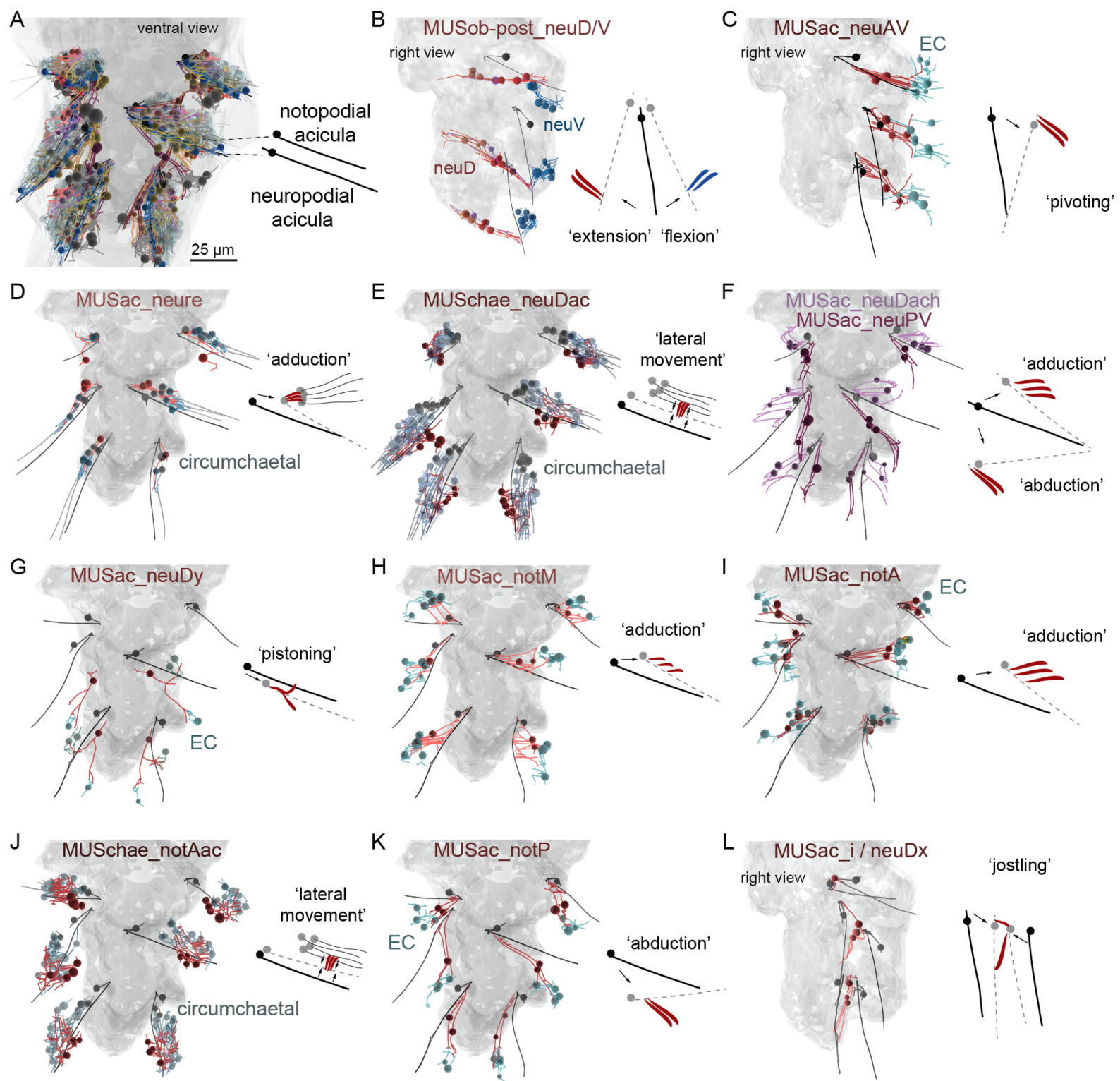

Figure 6 - figure supplement 3 . Muscles in the acicular complex and inferred movement of the aciculae.

(A) Skeleton view of the acicular complexes in all three parapodia. Each parapodium has a notopodial (dorsal) and a neuropodial (ventral) acicula. (B) The MUSobP-neu muscles (neuDdist, neuDLong, neuDprox) and the inferred movement of the neuropodial aciculae upon their contraction. MUSobPneuDlong cells connect to MUSlong-D, which are shown for reference. (C) The MUSac-neuAV muscles and the inferred movement of the neuropodial aciculae. (D) The MUSac-neure muscles and the inferred movement of the neuropodial aciculae and chaetae. (E) The MUSchae-neuDac muscles and the inferred movement of the neuropodial aciculae and chaetae. (F) The MUSac-neuDach and MUSac-neuPV muscles and the inferred movement of the neuropodial aciculae. (G) The MUSacneuDy muscles and the inferred movement of the neuropodial aciculae. $(H)$ The MUSac-notM muscles and the inferred movement of the notopodial aciculae. (I) The MUSac-notA muscles and the 
bioRxiv preprint doi: https://doi.org/10.1101/2021.06.09.447732; this version posted June 10, 2021. The copyright holder for this preprint (which was not certified by peer review) is the author/funder, who has granted bioRxiv a license to display the preprint in perpetuity. It is made available under aCC-BY-NC 4.0 International license.

inferred movement of the notopodial aciculae. (J) The MUSchae-notAac muscles and the inferred movement of the notopodial aciculae and chaetae. (K) The MUSac-notP muscles and the inferred movement of the notopodial aciculae. (L) The MUSac-i and MUSac-neuDx muscles and the inferred movement of the neuropodial and notopodial aciculae. B, C and $L$ are right lateral views, all other views are ventral views. The outline of the yolk is shown in grey for reference.

A
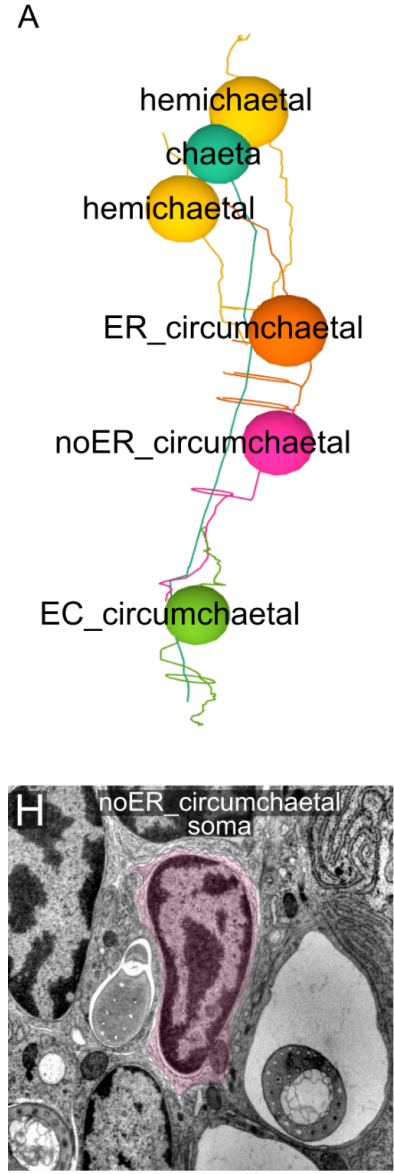
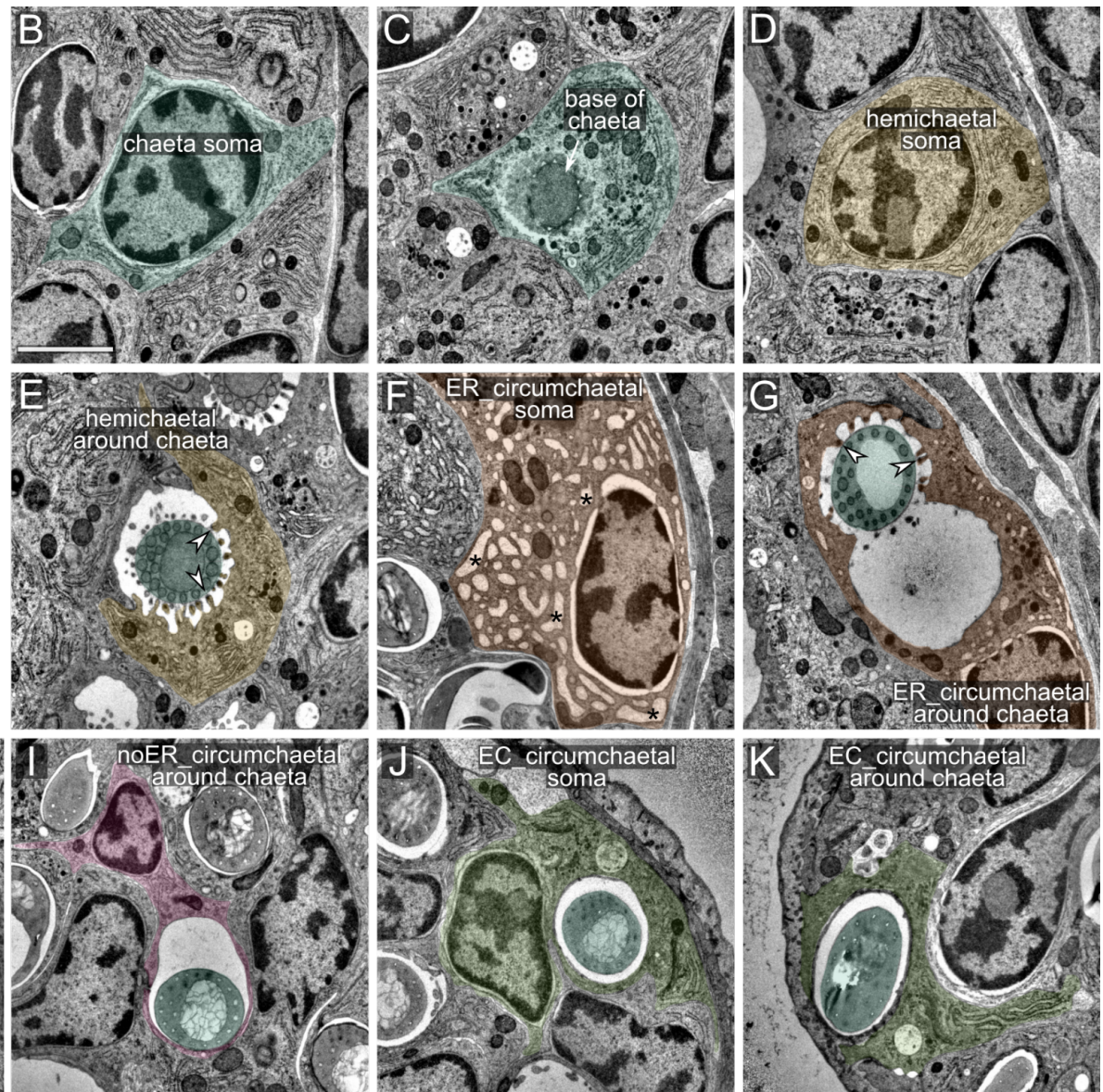
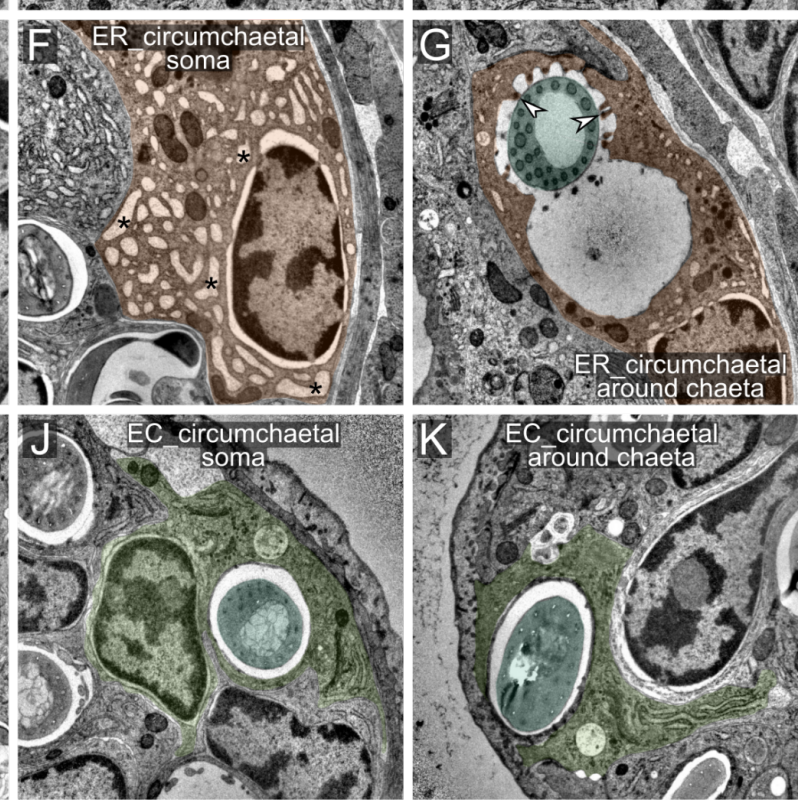

Figure 6 - figure supplement 4 . Ultrastructure of chaetal sac cells.

(A) Soma positions of chaetoblast and follicle cells. Each chaeta, growing from a chaetoblast cell is accompanied by two hemichaetal, one ER_circumchaetal, one noER_circumchaetal, and one EC_circumchaetal cell. (B) TEM image of the soma of a chaetoblast. (C) Chaetoblast at the base of the chaeta. (D) Soma of a hemichaetal cell. (E) Hemichaetal cell surrounding a chaeta from one side. Arrowheads mark microvilli with hemidesmosomes that connect to the chaeta. $(F)$ Soma of an ER_circumchaetal cell with its vacuolar characteristic ER. (G) ER_circumchaetal cell surrounding a chaeta. Arrowheads mark microvilli with hemidesmosomes that connect to the chaeta. $(H)$ Soma of a noER_circumchaetal cell with very little ER. (I) noER_circumchaetal cell surrounding a chaeta, no microvilli are present. (J) Soma of an EC_circumchaetal cell. (K) EC_circumchaetal cell surrounding a chaeta, no microvilli are present. Scale bar: $1 \mu \mathrm{m}$ for all panels. 


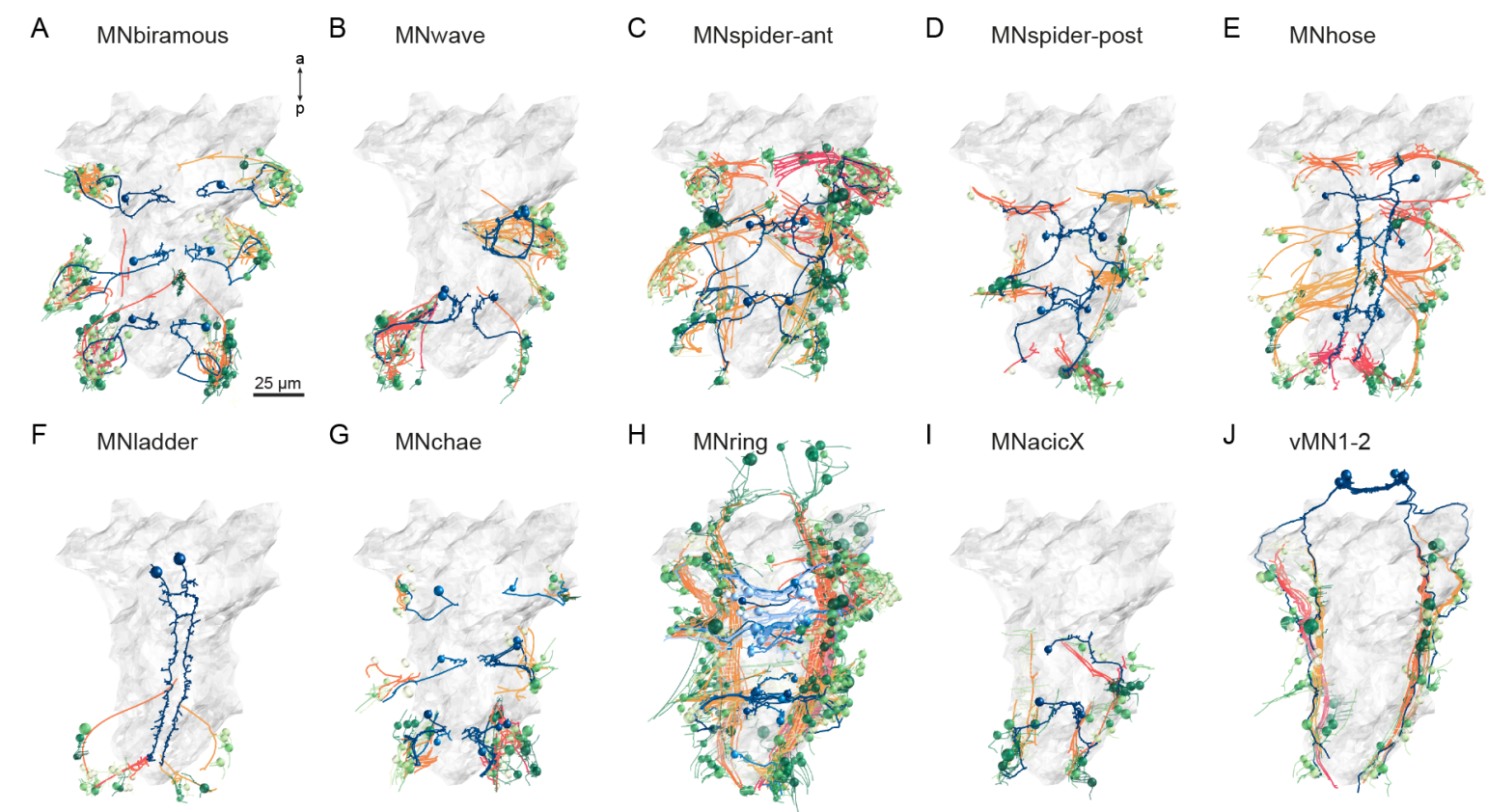

Figure 8 - figure supplement 1. Downstream synaptic and desmosomal partners of main motoneuron types.

(A-J) Muscle targets of 10 trunk motoneuron types (blue) in the 3-day-old larva, their postsynaptic muscle targets (orange-red) and the desmosomal partners of the innervated muscles (shades of green). The yolk outline is shown in grey for reference.

\section{Videos}

\section{Video 1. All muscles in the 3-day-old Platynereis larva}

Individual muscle cell-types are shown by cell type and muscle category. The 12 aciculae are shown in grey for reference. The cell somas are labelled by a sphere. The yolk and body outlines are shown in grey.

Video 2. Muscle groups in the parapodial complex.

Reconstruction of all cell groups in the left parapodial complex in the 2 nd segment. The neuropodial and notopodial aciculae are shown in black, chaetae are in yellow. The dark-brown cell with the large soma is the spinning gland. The yolk outline is shown in grey. CATMAID view:

https://catmaid.jekelylab.ex.ac.uk/11/links/bc9w96t

Video 3. 3D visualisation of all cells in the desmosomal connectome coloured by module.

The colour scheme is the same as in Figure 3 . The cell somas are labelled by a sphere. Individual $Z$ planes from the stack are also shown to indicate the orientation of the serial EM stack. The yolk and body outlines are shown in grey. CATMAID view:

https://catmaid.jekelylab.ex.ac.uk/?pid=11\&link=um2ydcf

Video 4. Acicular movements in crawling and startling Platynereis larvae

DIC video of a crawling larva and a startling larva (end of the video) with the position of the aciculae tracked by DeepLabCut. 
Video 5. Calcium imaging of muscle contractions in Platynereis larvae

Spontaneous contractions of individual muscle groups as visualised by the confocal imaging of calcium signals reported by GCaMP6s fluorescence. The larvae were also imaged in the DIC channel to reveal the movements of the parapodia.

\section{Video 6. 3D visualisation of motoneurons, their muscle targets and the desmosomal partners of the muscles}

The first half of the video shows the combined synaptic and desmosomal connectome of the MNcrab (shades of blue/purple) motoneurons. Synapses are shown in red, desmosomes in cyan. The muscles postsynaptic to the four MNcrab cells are shown in orange. The desmosomal partners of these muscle cells are shown in green. The second half of the video shows all motoneurons from the 12 analyses classes, their muscle partners and the desmosomal partners of those muscles.

CATMAID view: https://catmaid.jekelylab.ex.ac.uk/11/links/bdr5r6u

\section{References}

Albertson DG, Thomson JN. 1976. The Pharynx of Caenorhabditis elegans. Philosophical Transactions of the Royal Society B: Biological Sciences. doi:10.1098/rstb.1976.0085

Ayers T, Tsukamoto H, Gühmann M, Veedin Rajan VB, Tessmar-Raible K. 2018. A G-type opsin mediates the shadow reflex in the annelid Platynereis dumerilii. BMC Biol 16:41.

Bates AS, Manton JD, Jagannathan SR, Costa M, Schlegel P, Rohlfing T, Jefferis GS. 2020. The natverse, a versatile toolbox for combining and analysing neuroanatomical data. Elife $\mathbf{9}$. doi:10.7554/eLife.53350

Bergter A, Brubacher JL, Paululat A. 2008. Muscle formation during embryogenesis of the polychaete Ophryotrocha diadema (Dorvilleidae) - new insights into annelid muscle patterns. Front Zool 5:1.

Bezares-Calderón LA, Berger J, Jasek S, Verasztó C, Mendes S, Gühmann M, Almeda R, Shahidi R, Jékely G. 2018. Neural circuitry of a polycystin-mediated hydrodynamic startle response for predator avoidance. Elife 7. doi:10.7554/eLife.36262

Blondel VD, Guillaume J-L, Lambiotte R, Lefebvre E. 2008. Fast unfolding of communities in large networks. J Stat Mech 2008:P10008.

Brierley DJ, Rathore K, VijayRaghavan K, Williams DW. 2012. Developmental origins and architecture of Drosophila leg motoneurons. J Comp Neurol 520:1629-1649.

Brunet T, Fischer AH, Steinmetz PR, Lauri A, Bertucci P, Arendt D. 2016. The evolutionary origin of bilaterian smooth and striated myocytes. Elife 5. doi:10.7554/eLife.19607

Charles JP, Cappellari O, Spence AJ, Hutchinson JR, Wells DJ. 2016. Musculoskeletal Geometry, Muscle Architecture and Functional Specialisations of the Mouse Hindlimb. PLoS One 11:e0147669.

Clauset A, Newman MEJ, Moore C. 2004. Finding community structure in very large networks. Phys Rev E Stat Nonlin Soft Matter Phys 70:066111.

Conzelmann M, Williams EA, Tunaru S, Randel N, Shahidi R, Asadulina A, Berger J, Offermanns S, Jékely G. 2013. Conserved MIP receptor-ligand pair regulates Platynereis larval settlement. Proc Natl Acad Sci U S A 110:8224-8229.

Cruce WL. 1974. The anatomical organization of hindlimb motoneurons in the lumbar spinal cord of the frog, Rana catesbiana. J Comp Neurol 153:59-76.

de Joussineau C, Bataillé L, Jagla T, Jagla K. 2012. Diversification of muscle types in Drosophila: upstream and downstream of identity genes. Curr Top Dev Biol 98:277-301.

Doyle JK, Graver JE. 1977. Mean distance in a graph. Discrete Math 17:147-154.

Filippova A, Purschke G, Tzetlin AB, Müller MCM. 2010. Musculature in polychaetes: comparison of Myrianida prolifera (Syllidae) and Sphaerodoropsis sp. (Sphaerodoridae): Musculature of syllid and sphaerodorid polychaetes. Invertebr Biol 129:184-198.

Fischer A, Dorresteijn A. 2004. The polychaetePlatynereis dumerilii (Annelida): a laboratory animal with spiralian cleavage, lifelong segment proliferation and a mixed benthic/pelagic life cycle. BioEssays. doi:10.1002/bies.10409

Fischer AH, Henrich T, Arendt D. 2010. The normal development of Platynereis dumerilii (Nereididae, Annelida). Front Zool 7:31.

Francis R, Waterston RH. 1991. Muscle cell attachment in Caenorhabditis elegans. The Journal of 
Cell Biology. doi:10.1083/jcb.114.3.465

Gazave E, Lemaître QIB, Balavoine G. 2017. The Notch pathway in the annelid Platynereis: insights into chaetogenesis and neurogenesis processes. Open Biol 7. doi:10.1098/rsob.160242

Gieseler K, Qadota H, Benian GM. 2017. Development, structure, and maintenance of C. elegans body wall muscle. WormBook 2017:1-59.

Green KJ, Gaudry CA. 2000. Are desmosomes more than tethers for intermediate filaments? Nat Rev Mol Cell Biol 1:208-216.

Gühmann M, Jia H, Randel N, Verasztó C, Bezares-Calderón LA, Michiels NK, Yokoyama S, Jékely G. 2015. Spectral Tuning of Phototaxis by a Go-Opsin in the Rhabdomeric Eyes of Platynereis. Curr Biol 25:2265-2271.

Handberg-Thorsager M, Gutierrez-Mazariegos J, Arold ST, Kumar Nadendla E, Bertucci PY, Germain P, Tomançak P, Pierzchalski K, Jones JW, Albalat R, Kane MA, Bourguet W, Laudet V, Arendt D, Schubert M. 2018. The ancestral retinoic acid receptor was a low-affinity sensor triggering neuronal differentiation. Sci Adv 4:eaao1261.

Hausen H. 2005. Chaetae and chaetogenesis in polychaetes (Annelida). Developments in Hydrobiology 535:37-52.

Kuehn E, Stockinger AW, Girard J, Raible F, Özpolat BD. 2019. A scalable culturing system for the marine annelid Platynereis dumerilii. PLoS One 14:e0226156.

Lafontant PJ, Behzad AR, Brown E, Landry P, Hu N, Burns AR. 2013. Cardiac Myocyte Diversity and a Fibroblast Network in the Junctional Region of the Zebrafish Heart Revealed by Transmission and Serial Block-Face Scanning Electron Microscopy. PLoS ONE. doi:10.1371/journal.pone.0072388

Landmesser L. 1978. The distribution of motoneurones supplying chick hind limb muscles. J Physiol 284:371-389.

Lauri A, Brunet T, Handberg-Thorsager M, Fischer AHL, Simakov O, Steinmetz PRH, Tomer R, Keller PJ, Arendt D. 2014. Development of the annelid axochord: insights into notochord evolution. Science 345:1365-1368.

Liu J, Ou Q, Han J, Li J, Wu Y, Jiao G, He T. 2015. Lower Cambrian polychaete from China sheds light on early annelid evolution. Naturwissenschaften 102:34.

Mathis A, Mamidanna P, Cury KM, Abe T, Murthy VN, Mathis MW, Bethge M. 2018. DeepLabCut: markerless pose estimation of user-defined body parts with deep learning. Nat Neurosci 21:1281-1289.

McKellar CE, Siwanowicz I, Dickson BJ, Simpson JH. 2020. Controlling motor neurons of every muscle for fly proboscis reaching. Elife 9. doi:10.7554/eLife.54978

Mettam C. 2009. Segmental musculature and parapodial movement of Nereis diversicolor and Nephthys hombergi (Annelida: Polychaeta). J Zool 153:245-275.

Nakamura MJ, Terai J, Okubo R, Hotta K, Oka K. 2012. Three-dimensional anatomy of the Ciona intestinalis tailbud embryo at single-cell resolution. Dev Biol 372:274-284.

Nakao T. 1975. Fine structure of the myotendinous junction and "terminal coupling" in the skeletal muscle of the lamprey, Lampetra japonica. Anat $\operatorname{Rec} 182: 321-337$.

Özpolat BD, Handberg-Thorsager M, Vervoort M, Balavoine G. 2017. Cell lineage and cell cycling analyses of the $4 \mathrm{~d}$ micromere using live imaging in the marine annelid. Elife 6. doi:10.7554/eLife.30463

Poehn B, Krishnan S, Zurl M, Coric A, Rokvic D, Arboleda E, Orel L, Raible F, Wolf E, TessmarRaible K. n.d. A Cryptochrome adopts distinct moon- and sunlight states and functions as moonlight interpreter in monthly oscillator entrainment. doi:10.1101/2021.04.16.439809

Pumplin DW, Muller KJ. 1983. Distinctions between gap junctions and sites of intermediate filament attachment in the leech C.N.S. Journal of Neurocytology. doi:10.1007/bf01258152

Randel N, Asadulina A, Bezares-Calderón LA, Verasztó C, Williams EA, Conzelmann M, Shahidi R, Jékely G. 2014. Neuronal connectome of a sensory-motor circuit for visual navigation. Elife 3. doi:10.7554/eLife.02730

Randel N, Shahidi R, Verasztó C, Bezares-Calderón LA, Schmidt S, Jékely G. 2015. Inter-individual stereotypy of the Platynereis larval visual connectome. Elife 4:e08069.

Restrepo JG, Ott E, Hunt BR. 2006. Characterizing the dynamical importance of network nodes and links. Phys Rev Lett 97:094102.

Saalfeld S, Cardona A, Hartenstein V, Tomancak P. 2009. CATMAID: collaborative annotation toolkit for massive amounts of image data. Bioinformatics 25:1984-1986.

Schenk S, Krauditsch C, Frühauf P, Gerner C, Raible F. 2016. Discovery of methylfarnesoate as the annelid brain hormone reveals an ancient role of sesquiterpenoids in reproduction. eLife. doi:10.7554/elife. 17126 
bioRxiv preprint doi: https://doi.org/10.1101/2021.06.09.447732; this version posted June 10, 2021. The copyright holder for this preprint (which was not certified by peer review) is the author/funder, who has granted bioRxiv a license to display the preprint in perpetuity. It is made available under aCC-BY-NC 4.0 International license.

Schneider-Mizell CM, Gerhard S, Longair M, Kazimiers T, Li F, Zwart MF, Champion A, Midgley FM, Fetter RD, Saalfeld S, Cardona A. 2016. Quantitative neuroanatomy for connectomics in Drosophila. Elife 5. doi:10.7554/eLife.12059

Schneider SQ, Bowerman B. 2007. beta-Catenin asymmetries after all animal/vegetal- oriented cell divisions in Platynereis dumerilii embryos mediate binary cell-fate specification. Dev Cell 13:7386.

Steinmetz PRH, Kostyuchenko RP, Fischer A, Arendt D. 2011. The segmental pattern of otx, gbx, and Hox genes in the annelid Platynereis dumerilii. Evol Dev 13:72-79.

Traag VA, Waltman L, van Eck NJ. 2019. From Louvain to Leiden: guaranteeing well-connected communities. Sci Rep 9:5233.

Verasztó C, Jasek S, Gühmann M, Shahidi R, Ueda N, Beard JD, Mendes S, Heinz K, BezaresCalderón LA, Williams E, Jékely G. 2020. Whole-animal connectome and cell-type complement of the three-segmented Platynereis dumerilii larva. bioRxiv. doi:10.1101/2020.08.21.260984

Vergara HM, Bertucci PY, Hantz P, Tosches MA, Achim K, Vopalensky P, Arendt D. 2017. Wholeorganism cellular gene-expression atlas reveals conserved cell types in the ventral nerve cord of Platynereis dumerilii. Proceedings of the National Academy of Sciences. doi:10.1073/pnas.1610602114

Vopalensky P, Tosches MA, Achim K, Handberg-Thorsager M, Arendt D. 2019. From spiral cleavage to bilateral symmetry: the developmental cell lineage of the annelid brain. BMC Biol 17:81.

Williams EA, Conzelmann M, Jékely G. 2015. Myoinhibitory peptide regulates feeding in the marine annelid Platynereis. Front Zool 12:1.

Williams EA, Verasztó C, Jasek S, Conzelmann M, Shahidi R, Bauknecht P, Mirabeau O, Jékely G. 2017. Synaptic and peptidergic connectome of a neurosecretory center in the annelid brain. Elife 6. doi: $10.7554 /$ eLife. 26349

Zantke J, Oberlerchner H, Tessmar-Raible K. 2014. Circadian and Circalunar Clock Interactions and the Impact of Light in Platynereis dumerilii. Annual, Lunar, and Tidal Clocks. doi:10.1007/978-4431-55261-1_8

Žídek R, Machoň O, Kozmik Z. 2018. Wnt/ß-catenin signalling is necessary for gut differentiation in a marine annelid,. Evodevo 9:14.

Zurl M, Poehn B, Rieger D, Krishnan S, Rokvic D, Rajan VBV, Gerrard E, Schlichting M, Orel L, Lucas RJ, Wolf E, Helfrich-Förster C, Raible F, Tessmar-Raible K. 2021. Two light sensors decode moonlight versus sunlight to adjust a plastic circadian/circalunidian clock to moon phase. bioRxiv. doi:10.1101/2021.04.16.440114 